\author{
RAFAE RUTKOWSKI \\ https://orcid.org/0000-0002-1875-982X \\ Instytut Historii PAN, Warszawa
}

\title{
JAK OPOWIEDZIEĆ O ZWYCIĘSTWIE NAD CEZAREM? PRÓBA NOWEGO SPOJRZENIA NA PRZEKAZ MISTRZA WINCENTEGO (I, 17)*
}

\begin{abstract}
Abstrakt: Przedmiotem artykułu jest opowieść Mistrza Wincentego Kadłubka o potrójnym zwycięstwie Lestka III nad Juliuszem Cezarem i założeniu w Polsce dwóch miast przez siostrę tego ostatniego. Posługując się materiałem porównawczym, dowodzę, że opowieść ta została zbudowana z wędrownych motywów literackich, by pokazać niezależność Polski od Cesarstwa.

Słowa kluczowe: Juliusz Cezar, Lestek III, Wincenty Kadłubek, historiografia średniowieczna, dzieje bajeczne.
\end{abstract}

Abstract: The article deals with the story of Master Vincentius Kadłubek about the triple victory of Prince Lestek III over Julius Caesar and the foundation of two towns in Poland by the sister of the latter. With the use of comparative material, it is proved that this story was built on the basis of travelling literary motifs to show Poland's independence from the Empire.

Keywords: Julius Caesar, Lestek III, Vincentius Kadłubek, medieval historiography, fabulous history.

Juliusz Cezar ani razu nie został wspomniany przez Galla Anonima. W polskim dziejopisarstwie postać ta pojawia się dopiero na kartach drugiej naszej kroniki. Mistrz Wincenty siedemnasty rozdział pierwszej księgi swojego dzieła poświęcił panowaniu Lestka III $^{1}$. Władca ten miał

* Artykuł dedykowany jest mojemu Mistrzowi, Panu Profesorowi Jackowi Banaszkiewiczowi.

${ }^{1}$ Literature na temat kronikarza zestawiają: K. Kollinger, Vincentiana. Materiaty do bibliografii, w: Onus Athlanteum. Studia nad Kroniką biskupa Wincentego, red. A. Dąbrówka, W. Wojtowicz, Warszawa 2009, s. 476-527; W. Drelicharz, Idea zjednoczenia królestwa w średniowiecznym dziejopisarstwie polskim, Kraków 2012, s. 70-91. 
trzykrotnie pokonać Cezara, pobitego w Partii zaś Krassusa miał napoić płynnym złotem. Rozkazywał nie tylko Getom i Partom, ale nawet krainom położonym daleko za Partią. Odniesione zwycięstwa sprawiły takie wrażenie na Cezarze, że postanowił on spowinowacić się z władcą Lechitów i wydał za niego swoją siostrę Julię. Ta w posagu wniosła Lestkowi Bawarię. Założyła również „dwa bliźniacze miasta”, nazwane od jej i brata imion Julia i Juliusz. Ponieważ przyjazne gesty Cezara były na szkodę Imperium, w efekcie spotkały się z niechęcią Senatu. W związku z tym dyktator podjął próbę odbicia Bawarii z rąk swojego szwagra. Doprowadziło to do oddalenia z polskiego dworu Julii, która pozostawiła po sobie jedynego syna o imieniu Pompiliusz. Jej miejsce $u$ boku Lestka zajęła natomiast pewna nałożnica, która z zazdrości wobec rywalki zmieniła nazwy miast na te, pod którymi znane są one obecnie - odpowiednio Lublin i Lubusz².

Opowieść Mistrza Wincentego o relacjach Lestka III z Cezarem nie cieszyła się uznaniem historyków pozytywistów i marksistów ${ }^{3}$. Zdaniem Aleksandra Brücknera, „bajdy Juliuszowe”, będące objawem „bzika czy manii średniowiecza", miały zostać przejęte przez Słowian w wyniku kontaktów z Zachodem między VIII a XII w. ${ }^{4}$ Dla Eugeniusza Konika, średniowieczne przekazy poświęcone Cezarowi „nie zawsze [--] pokrywały się z prawdą", dlatego też stanowiły w jego oczach dowód na wulgaryzację kultury antycznej w epoce nieznającej jeszcze obiektywnych

2 „MATHEVS: Huius [Lestka II] item filius non tam patris imperio quam paternis multa adiecit uirtutibus. Qui Iulium Cesarem tribus fudit preliis, qui Crassum aput Parthos cum omnibus deleuit copiis, cuius ori aurum infundens: Aurum, inquit, sitisti, aurum bibe! Nam et Gethis et Parthis ac transparthanis regionibus imperauit. Huic tandem Iulius iure affinitatis gaudet federari, sororem nomine Iuliam eius matrimonio sociat eique iure dotis a fratre Bauaria, donatione uero propter nuptias a uiro Surbiensis contradita est prouincia. Hec geminas fundauit urbes, quarum unam a nomine fratris Iulius, que nunc Lubus, aliam a proprio uocabulo Iulin iussit appellari, que nunc Lublin nuncupatur. Quia enim Iulius hoc ex facto senatus in se conflauerat inuidiam, qui quasi hostis non quasi ciuis Romani propagationem artaret imperii, hostium illectus amplexibus et quos magis decuisset seruire, docuisset imperare, ea que nomine dotis contulerat, a sorore nititur extorquere. Qua ex causa soror eius passa est repudium, paruulo filio cui nomen Pompilius aput uirum relicto. Pelex autem eius, que presentem etiam emulata fuit reginam loco succedit. Hec odio emule $\mathrm{ab}$ amoris auspicio quo regem deuinxerat, predictarum nomina urbium transmutauit", Magistri Vincentii dicti Kadłubek Chronica Polonorum, wyd. M. Plezia, MPH n.s., t. 11, Kraków 1994, lib. I, cap. 17, s. 22 n.

${ }^{3}$ Poza niżej przytoczonymi, vide np. A. Małecki, Lechici w świetle historycznej krytyki, wyd. 2, Lwów 1907, s. 78; K. Ślaski, Wątki historyczne w podaniach o początkach Polski, Poznań 1968, s. 65.

${ }^{4}$ A. Brückner, Mitologia słowiańska i polska, wstęp i oprac. S. Urbańczyk, Warszawa 1980, s. 203 n. 
praw rządzących procesem historycznym ${ }^{5}$. Leszek Moczulski przeciwstawia natomiast sobie historie o rozgromieniu Cezara przez Lestka i o postrzyżeniu Siemowita, tę pierwszą uznając za falsyfikowalną, a drugą za niefalsyfikowalną, a więc potencjalnie wiarygodną ${ }^{6}$. Zdaniem Zenona Kałuży, opowieść o „kontaktach matrymonialnych i militarnych z Juliuszem Cezarem" była jedynie sztucznym konstruktem intelektualnym biskupa krakowskiego ${ }^{7}$. Przychylniejszym okiem spojrzeli na nią natomiast Kazimierz Tymieniecki, Aleksander Gieysztor, Czesław Deptuła, Jacek Banaszkiewicz i Marek Cetwiński. Zwrócili oni uwagę na jej ideowo-polityczny wymiar, mający podkreślić z jednej strony sięgające dawnych czasów związki Polski z Cesarstwem, a z drugiej jej polityczną niezależność względem niego ${ }^{8}$. Ostatnio Sławomir Gawlas spostrzegł, że celowi temu nieprzypadkowo służy odwołanie do postaci Cezara w takich

${ }^{5}$ E. Konik, Gajusz Juliusz Cezar w historiografii, „Annales UMCS”, sectio F, Nauki Humanistyczne, 29, 1974, s. 33 n. W istocie dzieło Kadłubka (jedyny średniowieczny przykład przywołany przez Konika) stanowi dowód ogromnego przywiązania do kultury antyku.

${ }^{6}$ L. Moczulski, Narodziny Międzymorza. Ukształtowanie ojczyzn, powstanie państw oraz układy geopolityczne wschodniej części Europy w późnej starożytności i we wczesnym średniowieczu, Warszawa 2007, s. 580, przyp. 697. Moczulski obserwację swoją oddaje „pod rozwagę niektórym współczesnym miłośnikom scjentystycznej baśniowości”. Notabene ten sam autor uważa za fakt historyczny, jakoby Siemowit został postrzyżony przez wysłanników Metodego i przypisuje tę informację Gallowi Anonimowi (s. 599, zwłaszcza przyp. 768). Tymczasem żadne średniowieczne źródło o tym nie mówi. Jest to de facto domysł nowożytnego historyka (A. Naruszewicz, Historya Narodu Polskiego, t. 4, Lipsk 1836, s. 15 n.), do którego wracano niekiedy - vide np. K. Lanckorońska, Studies on the Roman-Slavonic Rite in Poland, Roma 1961, s. 8 n.; K. Ślaski, op. cit., s. 80 n.; cf. też na temat późnośredniowiecznej ewolucji motywu dwóch wędrowców: Cz. Deptuła, Galla Anonima mit genezy Polski. Studium z historiozofii i hermeneutyki symboli dziejopisarstwa średniowiecznego, wyd. 2, Lublin 2000, s. 256-259, 268-270.

7 Z. Kałuża, Lektury filozoficzne Wincentego Kadłubka. Zbiór studiów, Warszawa 2014, s. 441.

${ }^{8}$ K. Tymieniecki, Polska legenda średniowieczna, „Przeszłość” 7, 1935, 4, s. 55-57; A. Gieysztor, Leszek I, II, III, w: SSS, t. 3, Wrocław 1967, s. 48 n.; Cz. Deptuła, Galla Anonima mit genezy, s. 332 n., 354-357; J. Banaszkiewicz, Polskie dzieje bajeczne Mistrza Wincentego Kadłubka, wyd. 2, Wrocław 2002, s. 259 n.; idem, Mistrz Wincenty i naśladowcy - wizje najstarszych dziejów Polski XIII-XV wieku, w: Przeszłość w kulturze średniowiecznej Polski, red. J. Banaszkiewicz [et al.], t. 1, Warszawa 2018, s. 288 n.; M. Cetwiński, Imperium Lechitów. Polityczna doktryna czy opowieść ku pokrzepieniu serc?, w: idem, Metamorfozy śląskie. Studia źródłoznawcze i historiograficzne, Częstochowa 2002, s. 71-77; idem, Juliusz Cezar w Lubiązu. Wokót pewnej wizji dziejopisarstwa ślaskiego, w: ibidem, s. 187-194. Ponadto: M.J. Karp, Więź ogólnopolska i regionalna w średniowiecznych mitach początku, PH 72, 1981, 2, s. 213 n.; P. Żmudzki, Vincentius's Construct of a Nation. Poland as Res Publica, w: Writing History in Medieval Poland. Bishop Vincentius of Cracow and the Chronica Polonorum, red. D. von Güttner-Sporzyński, Turnhout 2017, s. 180. 
źródłach jak Kaiserchronik czy Annolied przedstawianego jako twórca Cesarstwa i Rzeszy 9 .

W niniejszej pracy chciałbym uzupełnić spostrzeżenia wymienionych badaczy, przyglądając się „,bajdom Juliuszowym” (by pozostać przy barwnym określeniu Brücknera) w perspektywie porównawczej. Średniowieczne spojrzenie na postać Cezara będzie mnie zajmować w ograniczonym zakresie ${ }^{10}$. Nie dążę do wyczerpania problematyki, a jedynie do uzupełnienia pewnej luki z nią związanej. Odwołam się jedynie do takich średniowiecznych przekazów dotyczących rzymskiego dyktatora, które z opowieścią o Lestku III wykazują podobieństwo konstrukcji narracyjnej. Będą to teksty zarówno od dzieła biskupa krakowskiego niezależne, jak i od niego zależne. Moim celem będzie pokazanie, że w przekazie wyjściowym splecione zostały dwa, komparatystycznie uchwytne, wątki: zwycięstwo odniesione nad Cezarem i pamiątka po nim, która istnieje do tej pory, chociaż jej geneza zdążyła się już zatrzeć w pamięci potomnych. Interesuje mnie przy tym długie trwanie pewnych motywów literackich, stąd niekiedy porównywał będę teksty bardzo odległe w czasie (np. Izydor z Sewilli i Jan Długosz), jeżeli tylko są do siebie podobne. Sprawdzę wreszcie, jak przekaz Kadłubka był rozumiany przez późniejszych - polskich (w szczególności śląskich) i pomorskich - autorów. Jak się okaże, niektórzy z jego następców potrafili niekiedy „lepiej” od niego opowiedzieć historię Cezara.

Kadłubek zaczyna od informacji o dokonaniach Lestka, które - co znamienne - mieściły się raczej w sferze doskonalenia męstwa aniżeli podbojów terytorialnych ${ }^{11}$. Były to zwycięstwa odniesione nad Cezarem

9 S. Gawlas, Pytania o tożsamość średniowiecznych Polaków w świetle współczesnych dyskusji humanistyki, w: Symboliczne i realne podstawy tożsamości społecznej w średniowieczu, red. S. Gawlas, P. Żmudzki, Warszawa 2017, s. 53-66.

${ }^{10}$ Na temat średniowiecznych opowieści o Cezarze, vide np. F. Gundolf, Caesar in der deutschen Literatur, Berlin 1903; idem, Caesar. Geschichte seines Ruhms, Berlin 1925; H. Nearing jr., Local Caesar Traditions in Britain, „Speculum” 24, 1949, 2, s. 218-227; H. Thomas, Julius Caesar und die Deutschen. Zu Ursprung und Gestalt eines deutschen Geschichtsbewusstseins in der Zeit Gregors VII. und Heinrichs IV., w: Die Salier und das Reich, t. 3: Gesellschaftlicher und ideengeschichtlicher Wandel im Reich der Salier, red. S. Weinfurter [et al.], Sigmaringen 1991, s. 245-277; J. Strzelczyk, Juliusz Cezar $w$ tradycji wieków średnich, w: idem, W świecie średniowiecznych myśli i emocji. Wybór prac, Poznań 2012, s. 159-170. Nie miałem dostępu do: J.M.A. Beer, A Medieval Caesar, Genève 1976.

${ }^{11}$ Zdanie „non tam patris imperio quam paternis multa adiecit uirtutibus” doskonale mieści się w wewnętrznej logice dzieła Kadłubka, kronikarz wielokrotnie bowiem podkreśla pogardę dawnych Polaków dla poszerzania granic terytorialnych (vide J. Banaszkiewicz, Polskie dzieje bajeczne, s. 237-247; P. Żmudzki, Władca i wojownicy. Narracje o wodzach, drużynie $i$ wojnach $w$ najdawniejszej historiografii Polski i Rusi, Wrocław 2009, s. 249-252). Dopiero w późnym średniowieczu, u Piotra z Byczyny i Jana z Dąbrówki, 
i Krassusem ${ }^{12}$. Skupmy się na tym pierwszym, który miał ponieść w starciach z Lechitami trzykrotną porażkę. August Bielowski zakładał, że kronikarz, znając wydarzenia z tej samej epoki, ale z innych stron Europy, maskował je pod postacią opowiastki o polskich pradziejach. Otóż, jego zdaniem, „podania przez Mierzwę [sic!] i Wincentego skreślone odnoszą się osnową swoją do ludów zadunajskich, mianowicie do Ilirów, Getów, a nie do Polski" - dokładniej zaś do odnotowanej jakoby przez Appiana z Aleksandrii i Publiusza Watyniusza potrójnej porażki Cezara w walkach z tymi ludami ${ }^{13}$. Hipoteza ta wzbudza stanowczy sprzeciw. Pomijając, czy dzieła te mogły być znane Kadłubkowi, to żadne z nich nie zawiera tego, co wyczytał w nich Bielowski. Nie sposób zwłaszcza doliczyć się w nich trzech starć, które miałyby stanowić koronny argument w tej sprawie.

rozrost Lestkowego imperium zyskuje pewne znaczenie $\mathrm{w}$ zestawieniu $\mathrm{z}$ jego virtutes (Chronicon principum Poloniae, wyd. Z. Węclewski, MPH, t. 3, Lwów 1878, cap. 6, s. 434; Jan z Dąbrówki, Commentum in Chronicam Polonorum Magistri Vincentii dicti Kadłubek, wyd. M. Zwiercan [et al.], MPH n.s., t. 14, Kraków 2008, s. 45). W tym kontekście warto też zwrócić uwagę na informację, że Rzymian zirytowało zacieśnianie przez Cezara granic imperium na korzyść wrogów.

${ }^{12}$ Jeśli chodzi o Krassusa, znamienne, że Kadłubek przypisał Lestkowi dokonania króla Partów Orodesa, który (wedle Cycerona i Florusa) miał pochwycić i napoić płynnym złotem triumwira - vide np. K. Chmielewska, Rola wątków i motywów antycznych w „Kronice polskiej” Mistrza Wincentego zwanego Kadłubkiem, Częstochowa 2003, s. 117; Z. Kałuża, op. cit., s. 370-372. Wiadomość, że Lestek pokonał Krassusa aput Parthos ewoluowała w kolejnych wersjach opowieści. U Wielkopolanina Krassus stał się dowódcą Partów w Persji (Chronica Poloniae Maioris, wyd. B. Kürbis, MPH n.s., t. 8, Warszawa 1970, cap. 4, s. 10), u Jana z Dąbrówki natomiast ich królem i tyranem (Jan z Dąbrówki, Commentum in Chronicam, s. 46). Getami i Partami, nad którymi miał panować Lestek, Kadłubek konsekwentnie nazywał odpowiednio Prusów (Magistri Vincentii dicti Kadłubek Chronica Polonorum, lib. II, cap. 14, s. 47; lib. III, cap. 30, s. 126 n.; lib. IV, cap. 19, s. 166) i ludy koczownicze (lib. II, cap. 24, s. 70; lib. IV, cap. 14, s. 157), po dwakroć też zestawił Partów z Rusinami (lib. II, cap. 18, s. 55; lib. IV, cap. 24, s. 183; w tym kierunku idzie identyfikacja Partowie-Rusini u Jana z Dąbrówki). Nasuwa się wobec tego pytanie, czy w oczach polskich dziejopisarzy Krassus panował nad Rusinami bądź Połowcami. Ponadto: B. Kürbisówna, „Pollexianorum cervicosa feritas”. Dzikość $i$ barbarzyństwo w opinii Mistrza Wincentego, w: Słowianie w dziejach Europy. Studia historyczne ku uczczeniu 75 rocznicy urodzin i 50-lecia pracy naukowej profesora Henryka Łowmiańskiego, red. J. Ochmański, Poznań 1974, s. 131-138; J. Bieniak, Mistrz Wincenty w życiu politycznym Polski przełomu XII i XIII wieku, w: Mistrz Wincenty Kadłubek. Człowiek i dzieło, pośmiertny kult i legenda, red. K.R. Prokop, Kraków 2001, s. 44; P. Żmudzki, Władca i wojownicy, s. 76.

13 A. Bielowski, w: Mierzwy kronika, wyd. idem, MPH, t. 2, Lwów 1872, s. 179, przyp. 2-4, gdzie odwołanie do: idem, Wstęp krytyczny do dziejów Polski, Lwów 1850, s. 360-363 (Bielowski błędnie uważał kronikę Dzierzwy za starszą od dzieła Kadłubka). Nie wchodziłbym zapewne w polemikę z wydawcą, gdyby nie podjął on jako jedyny próby objaśnienia motywu „trzech bitew”, i gdyby nie powołała się na niego B. Kürbis, w: Mistrz Wincenty Kadłubek, Kronika Polska, Wrocław 2003, s. 30, przyp. 30. 
Appian wspomina bowiem o serii potyczek między Rzymianami a Dalmatami, w których Cezar brał jedynie epizodyczny udział, nie uczestnicząc zresztą osobiście $\mathrm{w}$ walkach (był bowiem wówczas pochłonięty konfliktem z Pompejuszem). Następująca potem wzmianka o Getach i Partach wydaje się zbieżnością przypadkową ${ }^{14}$. Watyniusz z kolei $\mathrm{w}$ liście do Cycerona lakonicznie wzmiankuje o wojennych działaniach Cezara w Dalmacji, nie podając jednak na ich temat żadnych konkretów ${ }^{15}$. Zresztą użyty przez Kadłubka zwrot tribus fudit preliis wydaje się być literacką kliszą - występuje on choćby trzykrotnie w głównym źródle, z którego biskup krakowski czerpał wiedzę o dziejach starożytnych, czyli w Epitomie Justyna ${ }^{16}-\mathrm{w}$ kontekstach jednak zgoła odmiennych ${ }^{17}$. Możliwe przecież, że podczas lektury fraza ta tak bardzo zapadła mu w pamięć, że sam się nią posłużył do swoich własnych celów.

Próba powiązania opowieści o potrójnym zwycięstwie nad Cezarem z rzeczywistymi wydarzeniami - związanymi czy niezwiązanymi z dziejami Polski - oznacza zatem niedopuszczalne rozbicie spójności przekazu i swobodne dobieranie składających się nań elementów ${ }^{18}$. Opowieść Kadłubka jest bowiem z jednej strony ahistoryczna, a z drugiej doskonale mieści się w średniowiecznych konwencjach przedstawiania

14 Appian's Roman History, wyd. i tłum. H. White, t. 2, London 1912, lib. X, cap. 11-13, s. $70,72,74,76$.

${ }^{15}$ Cicero, Epistulae ad familiares, wyd. D.R. Shackleton Bailey, t. 2: 47-43 BC, Cambridge 2004, ep. 256 (ep. fam. V, 10), s. 120.

16 Vide np. I. Lewandowski, Mistrz Wincenty a Justyn - epitomator Pompejusza Troga, „Studia Źródłoznawcze” 20, 1976, s. 28-34; K. Chmielewska, op. cit., s. 116-120.

17 Iustinus, Trogi Pompei Historiarum Philippicarum Epitoma, wyd. J.W.L. Jeep, Lipsiae 1859, lib. III, cap. 5, s. 31; lib. XXXVIII, cap. 4, s. 188; cap. 10, s. 194. Inne przykłady to m.in.: Krl 2, 13,25; Q. Curtii Rufi De Gestis Alexandri Magni regis Macedonum libri qui supersunt octo, wyd. J. Mützell, t. 1, Berlin 1841, lib. IV, cap. 6, § 35, s. 187; Eutropi Breviarium ab urbe condita, wyd. H. Droysen, MGH Auctores antiquissimi (dalej: MGH AA), t. 2, Berolini 1879, lib. VII, cap. 5, s. 116; Chronica Sigeberti Gemblacensis a. 381-1111, wyd. L.C. Bethmann, MGH SS, t. 6, Hannoverae 1844, s.a. 846, s. 339; Saxo Grammaticus, Gesta Danorum. The History of the Danes, wyd. K. Friis-Jensen, t. 1, Oxford 2015, lib. II, cap. 5, § 5, s. 108.

${ }^{18}$ Jeszcze dalej w dekontekstualizacji przekazu poszedł w swojej pracy doktorskiej (sic!) Piotr Makuch. Dopatrzył się on w opowieści Kadłubka refleksu dziejów Partów w epoce hellenistycznej, nie dostrzegając przy tym, że mowa wyraźnie o Polsce w czasach pierwszego triumwiratu - P. Makuch, Od Ariów do Sarmatów. Nieznane 2500 lat historii Polaków, Kraków 2013, s. 225-227. Problemu nie stanowi tu zatem bezkrytyczne, dosłowne przyjęcie przekazu, ale wręcz przeciwnie, graniczący z irracjonalizmem, naiwny krytycyzm. Praca Makucha nie spotkała się jak dotąd z odpowiednią repliką, vide jednak J. Filipiuk, K. Kośnik, Słowiańskie teorie spiskowe jako pozanaukowe narracje historyczne, „Czas Kultury” 2, 2016, s. 83; R. Żuchowicz, Wielka Lechia. Źródła i przyczyny popularności teorii pseudonaukowej okiem historyka, Warszawa 2018, s. 267; D.A. Sikorski, Religie dawnych Słowian. Przewodnik dla zdezorientowanych, Poznań 2018, s. 17 n. 
przeszłości. Jak wobec tego należy ją interpretować? Polacy nie byli jedynym ludem, który w średniowieczu przypisywał sobie zwycięstwo nad Cezarem. Motyw ten jest dobrze znany w gockiej tradycji historycznej ${ }^{19}$. Przykładowo Jordanes snuje następującą opowieść: „Cezar, który jako pierwszy spośród Rzymian stworzył imperium i prawie cały świat podporządkował swojej woli i wszystkie królestwa ujarzmił, a nawet zajął wyspy leżące poza naszym światem na oceanie, i tych, którzy imienia Rzymian ze słyszenia nie znali, rzymskimi trybutariuszami uczynił, Gotów jednak pomimo licznych prób nie zdołał podbić" ${ }^{20}$. Kronikarz ten podkreślił, że Cezar był pierwszym spośród władców rzymskich, którzy sięgnęli po imperialną władzę; w szczególny sposób zaznaczył jego ekspansywność, sięgającą nawet egzotycznych ludów spoza znanej ekumeny. Motyw ten znajduje analogię w Kronice Wielkopolskiej: o ile z dzieła Kadłubka nie wynika jednoznacznie, że to Cezar był stroną atakującą, o tyle Wielkopolanin podkreślił, że Lestek przed rzymską inwazją się bronił ${ }^{21}$. Podobnie było z zaatakowanymi Gotami. Jordanes wyraźnie przeciwstawił ekspansywność Cezara oporowi, jaki tamci mu stawili. Podkreślmy: oni i tylko oni pozostali niezależni wobec Rzymian. Również kolejne próby podporządkowania ich nie powiodły się - pozostali oni jedynym ludem wolnym od rzymskiego panowania, również za czasów Tyberiusza ${ }^{22}$. Konstantynopolitański dziejopis nie był jedynym, który wplótł w opowieści o Gotach wątek związany z Cezarem. Wedle Orozjusza, ludu tego mieli obawiać się i unikać tacy wielcy wodzowie starożytności jak Aleksander, Pyrrus i Cezar ${ }^{23}$.

19 Vide np. M. Reydellet, La royauté dans la littérature latine de Sidoine Apollinaire à Isidore de Séville, Rome 1981, s. 510-523; J. Wood, The Politics of Identity in Visigothic Spain. Religion and Power in the Histories of Isidore of Seville, Leiden-Boston 2012, s. 148 n.; R. Kasperski, Reges et gentes. Studia nad dyskursem legitymizującym władzę nad wspólnotami wyobrażonymi oraz strategiami ich konstruowania we wczesnym średniowieczu (VI-VII w.), Warszawa 2017, s. 97 n.

20 „Caesar vero, qui sibi primus omnium Romanum vindicavit imperium et pene omnem mundum suae dicioni subegit omniaque regna perdomuit, adeo ut extra nostro orbe in oceanis in ure positas insulas occuparet, et nec nomen Romanorum auditu qui noverant, eos Romanis tributarios faceret, Gothos tamen crebro pertemptans nequivit subicere”, Iordanis, Getica, wyd. Th. Mommsen, MGH AA, t. 5, 1, Berolini 1882, cap. 11, § 68, s. 73.

${ }^{21}$ „Tempore autem huius Lestkonis Julius Cesar Slaworum regna Romanorum imperio subicere contendens eciam fines Lechitarum invasit. Cui Lestko prefatus cum suis Lechitis fortissimis pro viribus resistens ter conflixit cum eodem stragem permaximam de populo Julii Cesaris faciendo", Chronica Poloniae Maioris, cap. 4, s. 10 n.

${ }^{22}$ "Gaius Tiberius iam tertius regnat Romanis: Gothi tamen suo regno incolume perseverant", Iordanis, Getica, cap. 11, § 68, s. 73.

${ }^{23}$ "Alexander euitandos pronuntiauit, Pyrrhus exhorruit, Caesar etiam declinauit", Orose, Histoires (contre les païens), wyd. M.-P. Arnaud-Lindet, Paris 2003, lib. I, cap. 16, $\S 2$, s. 66 . 
Zdanie Orozjusza zacytował Izydor z Sewilli, dodając opowieść o tym, jak Goci przyłączyli się do armii Pompejusza złożonej z rozmaitych ludów Orientu. I to właśnie oni (bardziej niż ich towarzysze broni) tak bardzo wystraszyli Cezara swoją liczbą i siłą, że rozważał on nawet ucieczkę z pola bitwy. Do walki ostatecznie jednak nie doszło, ponieważ nadszedł zmierzch. Izydor nie miał jednak wątpliwości co do tego, że Goci zadaliby Cezarowi druzgocącą klęskę ${ }^{24}$.

Podkreślić tu trzeba jeszcze jeden szczegół narracji Jordanesa, szczególnie dla nas istotny. Autor Getików powiedział mianowicie o Cezarze, że jako pierwszy „sibi [--] Romanum vindicavit imperium”. Z pewnością odnosi się to do chronologii cesarskich kadencji, skoro zaraz potem Tyberiusz został - wbrew stanowisku nowoczesnych historyków - określony jako trzeci imperator. Ponadto, uwaga ta koresponduje tak z badaną przez Sławomira Gawlasa epiką staroniemiecką, jak również z interesującą nas polską tradycją historiograficzną. Oto Dzierzwa w swojej wersji opowieści o Lestku III nazwał pokonanego przezeń Cezara „pierwszym monarchą"25. Komentując tę wzmiankę, Wojciech Drelicharz dopuścił dwie możliwości: albo Dzierzwa zaczerpnął ją bezpośrednio z Etymologii Izydora z Sewilli albo z izydoriańskich partii Rocznika kapituły krakowskiej ${ }^{26}$. Zarówno jednak u Izydora, jak i u annalisty zdanie mówiące, że Cezar „prior monarchiam tenuit”, było - niczego mu nie ujmując - jedynie luźną informacją rocznikarską ${ }^{27}$. Za sprawą Dzierzwy znalazło się w kontekście narracyjnym, do którego - jak to pokazuje gocka analogia świetnie pasuje. Tym samym, pokonanie Cesarstwa Rzymskiego i wynikła stąd niezależność od niego sięgają samych początków jego istnienia.

Opowieść o konfrontacji Cezara z ludami spoza limesu - również Polakami - mogła zresztą przybrać formę à rebours w stosunku do przekazów Kadłubka, Jordanesa czy Izydora. Innymi słowy, wojna z Rzymianami mogła zakończyć się klęską Polaków i Franków, o czym pisał trzynastowieczny niemiecki poeta Jansen Enikels. Obydwa ludy zostały zatem pokonane przez Cezara już w czasach antycznych, a tym samym

${ }^{24}$ Isidori Iunioris episcopi Hispalensis Historia Gothorum Wandalorum Sueborum, wyd. Th. Mommsen, MGH AA, t. 11, Berolini 1894, cap. 2-3, s. 268 n.

${ }^{25}$ Chronica Dzirsvae, wyd. K. Pawłowski, MPH n.s., t. 15, Kraków 2013, s. 15; cf. J. Banaszkiewicz, Kronika Dzierzwy. XIV-wieczne kompendium historii ojczystej, Wrocław 1979, s. 61.

${ }^{26}$ W. Drelicharz, Annalistyka małopolska XIII-XV wieku. Kierunki rozwoju wielkich roczników kompilowanych, Kraków 2003, s. 367 n.

${ }^{27}$ Isidori Hispalensis episcopi Etymologiarvm sive Originvm libri XX, wyd. W.M. Lindsay, Oxonii 1911, lib. V, cap. 39, § 25, [b.pag.]; Rocznik Kapituły Krakowskiej, wyd. Z. Kozłowska-Budkowa, MPH n.s., t. 5, Warszawa 1978, s. 28. 
już wówczas podporządkowane Cesarstwu ${ }^{28}$. Mimo że znaleźliśmy się na antypodach wincentyńskiej wizji historii Polski, to widzimy, jak użyteczną postacią był Cezar w opowieściach o dziejach bajecznych.

Zestawienie przekazów mówiących o Gotach z opowieścią Kadłubka jest o tyle interesujące, że u Jordanesa, Orozjusza i Izydora nie ma mowy o zawarciu porozumienia z Cezarem, ani tym bardziej o żadnej „pamiątce” po takim porozumieniu. U Mistrza Wincentego są nią dwa „bliźniacze miasta” założone przez Julię - Lublin i Lubusz. Jak dowodził Jacek Banaszkiewicz, wyznaczają one zachodnią i wschodnią rubież współczesnej kronikarzowi Polski ${ }^{29}$. Pamięć o genezie tych miejscowości nie była pielęgnowana na szczeblu lokalnym, tylko miała charakter ogólnopolski. Charakterystyczne też, że gdy w późnym średniowieczu przerabiano opowieść, zmieniano również nazwy cezariańskich miast. W pojedynczych kopiach Kroniki Polskiej ${ }^{30}$ i Kroniki Dzierzwy $^{31}$, a także w Kronice ksiażąt polskich ${ }^{32}$, Lublin zmienił się bowiem

${ }^{28}$ J. Enikels, Weltchronik, wyd. P. Strauch, MGH Deutsche Chroniken, t. 3, Hannoverae-Lipsiae 1900, v. 21083-21084, s. 414: „Franken unde Polân wart | Juljô allez undertân"; cf. A.F. Grabski, Polska w opiniach obcych X-XIII w., Warszawa 1964, s. 160-164.

${ }^{29}$ J. Banaszkiewicz, Polskie dzieje bajeczne, s. 259 n.; cf. G. Myśliwski, Archetypy i historia. Uwagi o „Polskich dziejach bajecznych mistrza Wincentego Kadłubka” Jacka Banaszkiewicza, PH 90, 1999, 4, s. 546, 548.

30 Chronicon Polono-Silesiacarum, wyd. W. Arndt, MGH SS, t. 19, Hannoverae 1866, s. 557, wraz z przyp. y; Chronicon Polonorum, wyd. L. Ćwikliński, MPH, t. 3, Lwów 1878, s. 614, wraz z przyp. 20: „aliam nomine suo, que nunc Lubin vocatur”. W miejsce anachronicznej Kroniki polsko-śląskiej posługuję się tytułem potwierdzonym przez rękopisy - o tym źródle, vide np. R. Michałowski, Princeps fundator. Studium z dziejów kultury politycznej w Polsce X-XIII wieku, wyd. 2, Warszawa 1993, s. 115 n.; W. Mrozowicz, Ślaska Kronika Polska. Wstęp do studium źródłoznawczego, cz. 1, w: Studia z historii średniowiecza, red. M. Goliński, Wrocław 2003, s. 105-128; idem, Z problematyki recepcji Kroniki Wincentego w średniowiecznym dziejopisarstwie polskim (ze szczególnym uwzględnieniem ślaskiej Kroniki Polskiej), w: Onus Athlanteum, s. 326-336; W. Drelicharz, Idea zjednoczenia królestwa, s. 199-240. Na temat tendencji opowieści o Lestku i Cezarze - J. Mularczyk, Kronika Polska i jej relacja o bitwie pod Studnica, KH 95, 1988, 2, s. 30 n.

31 Tak podaje Mierzwy Kronika, cap. 16, s. 179, wraz z przyp. 6: „aliam a suo proprio nomine Iulia, quae nunc Lubin dicitur". W edycji Pawłowskiego stoi jednak Lublin, bez podania wariantów tekstowych (Chronica Dzirsvae, s. 15). O tym źródle, vide J. Banaszkiewicz, Kronika Dzierzwy, passim; W. Drelicharz, Annalistyka małopolska, s. 333-373; idem, Idea zjednoczenia królestwa, s. 295-315. Nie znalazłem w literaturze informacji, czy Dzierzwie dostępny był tekst Kroniki Polskiej, a zatem, czy wzmiankę o Lubiniu można wyjaśnić filiacją genetyczną.

${ }^{32}$ Chronicon principum Poloniae, cap. 6, s. 434: „aliam suo nomine, que nunc Lubin vocatur". Od czasów Romana Hecka Kronika ksiażąt polskich nie doczekała się systematycznych studiów, vide R. Heck, Kronika ksiażąt polskich - metoda prezentacji dziejów, w: Dawna historiografia ślaska. Materiały sesji odbytej w Brzegu w dniach 26-27 listopada 
w Lubin' ${ }^{33}$, w Kronice Wielkopolskiej zaś - w zależności od rękopisu $\mathrm{w}$ Wolin albo w Berlin ${ }^{34}$. Pomińmy to drugie miasto, którego nazwę dopisano w jednej z kopii ręką nowożytną ${ }^{35}$. Uwagę zwraca raczej wzmianka o Wolinie, która - jak sądził Czesław Deptuła - miałaby świadczyć o morskich ambicjach Królestwa Polskiego ${ }^{36}$. Przede wszystkim jednak powstaje pytanie, czy Wielkopolaninowi nie była przypadkiem znana zapisana w żywotach św. Ottona tradycja, która wiązała założenie JulinaWolina z osobą Cezara. Mieszkańcy mieli nawet otaczać czcią włócznię należącą niegdyś do rzymskiego wodza. Przechowywana ona była bądź to $\mathrm{w}$ kącinie, bądź była wbita $\mathrm{w}$ wysoką kolumnę ${ }^{37}$. Skoro miasto zostało

1977 roku, Opole 1977, s. 61-81; idem, Chronica Principum Poloniae a Chronica Polonorum, Sobótka 31, 1976, 2, s. 185-196.

33 Vide M. Dembińska, A. Wędzki, Lubiń, w: SSS, t. 3, s. 96-98.

${ }^{34}$ Chronica Poloniae Maioris, cap. 4, s. 10 n.: "Julin quod nunc Volin appellavit”. Podsumowanie dyskusji na temat genezy tej kroniki, vide W. Drelicharz, Idea zjednoczenia królestwa, s. 357-384; P. Żmudzki, Kulturowy kontekst nazw „Polanie”, „Polacy”, „Polska” w średniowiecznej historiografii polskiej i ruskiej, w: Symboliczne i realne podstawy, s. 179, przyp. 56. Wielkopolanin (piszący - jak przyjmuję - w XIV w.) w największym stopniu rozbudował pierwotną opowieść Kadłubka. Zwracano uwagę na jego zależność od Dzierzwy, która w tym wypadku sprowadza się do informacji o śmierci Lestka za panowania Nerona, vide W. Drelicharz, Annalistyka małopolska, s. 214; z przeciwnej strony, cf. E. Skibiński, Początki Polski w Kronice Polskiej i w Kronice Dzierzwy, w: Cognitioni Gestorum. Studia z dziejów średniowiecza dedykowane Profesorowi Jerzemu Strzelczykowi, red. D.A. Sikorski, A.M. Wyrwa, Poznań-Warszawa 2006, s. 201. Poza tym kronikarz rozwinął własne skrzydła (czego chyba nie docenił dostatecznie Jacek Banaszkiewicz, Kronika Dzierzwy, s. 89). Na początku podkreślił ekspansywność Cezara, któremu Lestek trzykrotnie zwycięsko stawił czoła. Następnie Cezar, przebywając w Slawonii, wychodzi z propozycją zawarcia z Lestkiem przymierza. Drobiazgiem, choć może znaczącym, jest pominięcie informacji o wianie w postaci Serbii Łużyckiej. Julia, będąc już żoną Lestka, zakłada z woli męża dwa potężne grody. Nie słyszymy nic o późniejszej zmianie ich nazw przez nałożnicę. Po narodzinach syna Julia powiadamia o nich swojego brata, który - przebywając wciąż w Slawonii - ucieszony z posiadania siostrzeńca nadaje mu imię Pompiliusz (dokonana uprzednio przez Kadłubka zamiana Gallowego Popiela w Pompiliusza zyskuje w ten sposób swoje objaśnienie). Następnie dowiadujemy się, że Cezar, tytułowany jako Slauis victor, wraca do Rzymu w towarzystwie sprzymierzonych z nim Lechitów (rzuca się w oczy konsekwentne odróżnianie tychże od Słowian). Gdy Lechici wracają z Rzymu, wówczas Rzymianie okazują niezadowolenie czynami Cezara, w wyniku czego ten cofa darowiznę Bawarii, Julia zaś zostaje przez Lestka odprawiona. Z drugiej strony, brak w wielkopolskiej wersji opowieści Kadłubka amplifikacji wprowadzonych do niej uprzednio przez Dzierzwę, jak choćby tytułu primus monarcha.

35 B. Kürbis, w: Chronica Poloniae Maioris, cap. 4, s. 11, przyp. *.

${ }^{36}$ Cz. Deptuła, Ideologia Polski jako państwa morskiego $w$ dziejopisarstwie polskim XIIXIV wieku, „Zeszyty Naukowe KUL” 18, 1975, 4, s. 14 n.

$37 \mathrm{Na}$ ten temat, wraz z odwołaniami źródłowymi, vide np. A. Gieysztor, Mitologia Słowian, wyd. 2, Warszawa 2006, s. 151 n.; L.P. Słupecki, Slavonic pagan sanctuaries, 
założone przez Rzymian, to i kult pogański, który był w nim sprawowany, musiał mieć rzymski charakter ${ }^{38}$. Podobnie, wedle Kroniki ksiażąt polskich i Versus Lubenses, w powiązanym z Cezarem Lubiążu czczone miały być niegdyś posągi Juliusza i Marsa. Na miejscu dawnej pogańskiej świątyni stanął jednak później klasztor cysterski ${ }^{39}$.

Problem w tym, że Otton z Bambergu, podobnie jak jego hagiografia, nie wydaje się być w ogóle znany w późnośredniowiecznej Polsce, a więc i informacja ta była Wielkopolaninowi raczej niedostępna ${ }^{40}$. Trudno

Warsaw 1994, s. 83-90; D. Pandowska, Włócznia Juliusza Cezara w Wolinie, „Słupskie Studia Historyczne" 5, 1997, s. 27-37; A. Kuczkowski, Wolińska włócznia Juliusza Cezara - próba interpretacji, w: Kultura ludów Morza Bałtyckiego, t. 1: Starożytność i średniowiecze, red. M. Bogacki, M. Franz, Z. Pilarczyk, Toruń 2008, s. 408-421.

38 Vide M. Cetwiński, „Per totam civitatem ludos scenicos agi”. Teatr na Pomorzu w XII wieku?, w: idem, Metamorfozy ślaskie, s. 24; M. Cetwiński, M. Derwich, Herby, legendy, dawne mity, Wrocław 1989, s. 39-41; S. Rosik, Conversio gentis Pomeranorum. Studium świadectwa o wydarzeniu (XII wiek), Wrocław 2010, s. 239.

39 „Et tunc idem Boleslaus altus, zelo devocionis accensus, in situ castri Lubens, ubi, sicut dicitur, antiquitus tempore Iulii Cesaris, qui hoc ipsum construxisse narratur, fuit fanum idolorum, fundavit cenobium Cisterciensis ordinis", Chronicon principum Poloniae, cap. 18, s. 482; „Est locus iste Lubens Julio de Cesare dictus, | Slavonizando loquens consuevit dicere vulgus | Lubens pro Julius, qui primus castra metatus | Est hic, et populus eius phanum veneratus", Versus Lubenses, wyd. A. Bielowski, MPH, t. 3, Lwów 1878, s. 708 n. O Versus Lubenses szerzej, vide A. Pleszczyński, Przekazy niemieckie o Polsce i jej mieszkańcach w okresie panowania Piastów, Lublin 2016, s. 180-187; idem, J. Sobiesiak, K. Szejgiec, M. Tomaszek, P. Tyszka, Historia communitatem facit. Struktura narracji tworzacych tożsamości grupowe $w$ średniowieczu, Wrocław 2016, s. 41-64. Andrzej Pleszczyński sądzi, że wyrażony w poemacie pogląd o cezariańskiej genezie Lubiąża został wywiedziony bezpośrednio z opowieści Kadłubka o dwóch grodach założonych przez Julię. Pleszczyński upraszcza przy tym, mówiąc, że jednym z tych grodów był właśnie Lubiąż, a nie Lublin czy Lubusz (co nie przeszkadzałoby oczywiście poecie zmienić jego lokalizacji, tak jak wcześniej robili to inni kronikarze późnośredniowieczni). Poeta wprawdzie odwołuje się wprost do Mistrza Wincentego („Sicut de cronica transscripsi Cracowiana" - s. 710), bardziej prawdopodobna wydaje się jednak jego zależność od Kroniki ksiażąt polskich. U Piotra z Byczyny opowieść o pradziejach klasztoru cysterskiego stanowi zaś osobną całość w stosunku do historii Lestka III, nawet jeśli została nią zainspirowana. W kwestii relacji genetycznej między poematem a kroniką, vide M. Cetwiński, Juliusz Cezar w Lubiążu, passim, gdzie także wyczerpująca analiza wątków cezariańskich związanych z Lubiążem.

${ }^{40}$ Nieprzydatna jest dla mnie hipoteza Mariana Plezi i Marka Cetwińskiego, którzy (z różnych względów i niebezpodstawnie skądinąd) przypuszczali, że Kadłubkowi mógł być znany Dialog Herborda. Spośród trzech hagiografów ten akurat podaje najmniej informacji na temat cezariańskiej genezy Wolina - vide M. Plezia, Dialog w kronice Kadłubka, w: idem, Scripta minora. Łacina średniowieczna i Wincenty Kadłubek, Kraków 2001, s. 223 n.; M. Cetwiński, Podstępem czy siłą? „Działania specjalne” i ich moralna ocena w kronikach śląskich, „Średniowiecze polskie i powszechne” 2, 2002, s. 138-166. 
zatem wyjaśnić, w jaki sposób w jego przekazie znalazła się wzmianka o Wolinie. Do zręcznego zespolenia obydwu tradycji cezariańskich, polskiej i pomorskiej, doszło natomiast w spisanym w połowie XIV w. Protokole Augustyna (Angelusa) ze Stargardu, mającym uzasadnić, dlaczego Pomorze Zachodnie było zawsze politycznie i diecezjalnie niezależne od Polski ${ }^{41}$. Pomorski polemista twierdził, że Julin (obecnie znany jako Wolin) został założony przez Cezara na miejscu zburzonej uprzednio przez Słowian Winety ${ }^{42}$. Ponadto, wiedział on z Kroniki Polskiej, że siostra Cezara założyła w Polsce dwa grody, a od Helmolda, że uczeni ludzie uważają Wołogoszcz za miasto zbudowane przez niego samego ${ }^{43}$. Augustyn zespolił wszystkie te informacje w następującą całość: źródeł niezgody pomiędzy Polakami a Pomorzanami należy upatrywać w czasach Attyli, pierwszego króla Wandalów (czyli Słowian), współczesnego Aleksandrowi Wielkiemu. Niezgoda ta żywotna była również w czasach Cezara, który zbudował contra Polonos dwa warowne grody na Pomorzu. Były to właśnie Wolin i Wołogoszcz, zwane pierwotnie Julin i Julia Augusta ${ }^{44}$. Jak się wydaje, informacja ta stanowi echo opowieści o dwóch, noszących te same nazwy, miastach, które ufundowała polska królowa (choć to tylko hipoteza). Polemista, wiedząc o nich z Kroniki Polskiej, zachował ich nazwy i liczbę, zmienił natomiast ich lokalizację i okoliczności powstania. Tym samym zmieniona została wymowa tego faktu.

Wróćmy tymczasem do śledzenia dokonanych przez kolejnych autorów zmian w nazwach miast założonych przez siostrę Cezara. Do pierwotnej identyfikacji Julii z Lublinem wrócił Jan z Dąbrówki, odnotowując

${ }^{41}$ O tym źródle, vide R. Walczak, „Protocollum” augustianina-eremity zwanego Angelusem ze Stargardu. O polsko-pomorskich zwiazkach historiograficznych w średniowieczu, Poznań 1991, gdzie argumenty za tym, że imię polemisty brzmiało Augustyn, a nie - jak dawniej przyjmowano - Angelus.

${ }^{42}$ Notula satis notabilis de Pomeranorum, Stetinensium, ac Rugie principatu, wyd. J.G.L. Kosegarten, „Baltische Studien” 17, 1858, 1, s. 108, 113, 125; Augustyn ze Stargardu, Protokót, wyd. E. Rymar, Stargard 2008, s. 44, 54, 74. Na temat Winety, vide R. Kiersnowski, Legenda Winety. Studium historyczne, Kraków 1950; M. Rusakiewicz, Wineta. Korzenie legendy i jej recepcja w historiografii zachodniopomorskiej do XVI wieku, Wrocław 2016.

${ }^{43}$ Chronicon Polonorum, s. 614; ,ad urbem quae dicitur Woligost, apud urbaniores vocatur Iulia Augusta propter urbis conditorem Iulium Cesarem", Helmoldi Presbyteri Bozoviensis Cronica Slavorum, wyd. B. Schmeidler, MGH SrG in us. schol., Hannoverae 1937, lib. I, cap. 38, s. 74. W sprawie zależności polemisty od obydwu kronik, vide R. Walczak, op. cit., s. 217,239 n.

${ }^{44}$ Notula satis notabilis, s. 109; "Julii Cesaris tempore, qui in terra Pomeranie contra Polonos urbes construxit munitas, scilicet Julin et Wolgast, tunc Julia Augusta ab eodem sic dicta", Augustyn ze Stargardu, op. cit., s. 48. O wątkach cezariańskich w Protokole, vide J. Banaszkiewicz, Polskie dzieje bajeczne, s. 252, 266; M. Rusakiewicz, op. cit., s. 63-75. 
przy okazji, że Lubusz mieści się obecnie w Saksonii ${ }^{45}$. Wreszcie kasztelan międzyrzecki Jan Ostroróg w oracji wygłoszonej przed Pawłem II w 1467 r. wychwalał zwycięstwa polskiego oręża, dokonane nie tylko w czasach sobie współczesnych, ale również - jak dziś byśmy powiedzieli - w bajecznych ${ }^{46}$. Przedstawił on wizję Polski jako antemurale i królestwa „mlekiem i miodem płynącego”, które nie zostało przez nikogo podbite ${ }^{47}$. Ubolewał przy tym, że jej dzieje nie zostały odnotowane przez takich sławnych antycznych historyków jak Liwiusz, Justyn czy Florus. Ich milczenie rekompensowało wszakże świadectwo apokryficznej (wedle naszej dzisiejszej wiedzy) korespondencji Arystotelesa. Pisząc o (trzykrotnym, rzecz jasna) rozgromieniu wojsk Cezara, w ogóle zrezygnował z postaci Lestka i jego żony jako założycielki dwóch grodów. Stroną porozumienia z Rzymianami jest tu Polska. Na jego mocy polscy pasterze otrzymali od Rzymian Wilno ${ }^{48}$. Obserwacja ta stanowić może ciekawy, choć nieodnotowany przez badaczy, przyczynek do nowożytnej legendy o rzymskim pochodzeniu Litwinów ${ }^{49}$.

${ }^{45}$ Jan z Dąbrówki, Commentum in Chronicam, s. 46. O tym źródle, vide M. Zwiercan, Komentarz Jana z Dąbrówki do Kroniki Mistrza Wincentego zwanego Kadłubkiem, Wrocław 1969; W. Drelicharz, Idea zjednoczenia królestwa, s. 385-395; P. Węcowski, Początki Polski w pamięci historycznej późnego średniowiecza, Kraków 2014, s. 42-64. Także referaty opublikowane w tomie: Komentarz Jana z Dąrówki do Kroniki biskupa Wincentego, red. A. Dąbrówka, M. Olszewski, Warszawa 2015.

${ }^{46}$ O tym źródle, vide M. Cetwiński, Imperium Lechitów, s. 71 n.; K. Obremski, Panegiryczna sztuka postaciowania. August II Mocny, Toruń 2003, s. 73-81; P. Żmudzki, Kulturowy kontekst nazw, s. 187-191, który wskazuje na zależność Ostroroga od Kroniki Wielkopolskiej.

${ }^{47} \mathrm{~W}$ pierwszej kwestii, vide J. Tazbir, od antemurale do przedmurza, dzieje terminu, OiRP 29, 1984, s. 169 n., gdzie notabene błędne imię papieża, przed którym Ostroróg wygłosił orację. W literaturze nie dostrzeżono natomiast zapożyczonej być może od Galla wizji obfitującego we wszelkie dobra Królestwa, które nigdy nie uległo niczyjej sile (Galli Anonymi Cronicae et gesta ducum sive principum Polonorum, wyd. K. Maleczyński, MPH n.s., t. 2, Kraków 1952, ks. I, prolog, s. 8; cf. np. Cz. Deptuła, Galla Anonima mit genezy, s. 155 n.). Polska jest tym samym wyłączona z ciągu translatio imperii, rozpoczętego przez Asyryjczyków, a zakończonego przez Rzymian (cf. J. Banaszkiewicz, Polskie dzieje bajeczne, s. 250 n.). Zadaje to zresztą kłam twierdzeniu, jakoby w późnym średniowieczu Kronika Galla znalazła się w cieniu dzieła Kadłubka (vide np. P. Węcowski, op. cit., s. 35-42).

48 "Julius insuper Caesar tribus proeliis fusus cum hac [cum Polonia] foedus pepigit, in cujus signum datus erat pastoribus ejus locus - Julia civitas, quae nunc est Lituaniae caput. Tacuit hoc Livius, Justinus, Florus, quia Romani; ego annales Polonorum volui recensere; aliud Aristotelis epistolae bene comprobant", Mowa Ostroroga wobec papieża Pawła II (1467), w: Humanizm i reformacja w Polsce. Wybór źródeł dla ćwiczeń uniwersyteckich, wyd. I. Chrzanowski, S. Kot, Lwów 1927, s. 57. Wzmianka o Cezarze doczekała się repliki (Wiersze wywołane mowa Ostroroga, w: ibidem, s. 59).

${ }^{49} \mathrm{Na}$ ten temat wraz z dalszą literaturą, vide J. Jurkiewicz, Legenda o rzymskim pochodzeniu Litwinów w świetle historiografii. Czas powstania i tendencje polityczne, w: Europa 
Nie tylko średniowieczni autorzy polscy pisali o miastach założonych przez Cezara i nazwanych od jego imienia. Przykłady możnaby zapewne mnożyć w nieskończoność, tym bardziej że zostały one już wyeksploatowane przez badaczy, ograniczmy się zatem do kilku spośród nich. Słyszeliśmy już od Helmolda o założeniu Wołogoszczy przez Cezara. Paweł Diakon wspomina $\mathrm{z}$ kolei o cezariańskiej genezie Forum Iuliii ${ }^{50}$, Widukind zaś o tym, że Akwizgran leży niedaleko Jülich, założonego przez Juliusza $^{51}$. Wzmianki te są niezwykle lakoniczne i pojawiają się w tekstach zupełnie mimochodem, warto zwrócić jednak uwagę na dwa szczegóły w nich obecne. Otóż żaden z tych kronikarzy nie posłużył się postacią Julii, która w opowieści Kadłubka występowała niejako w zastępstwie swojego brata ${ }^{52}$ - to on sam miał być twórcą, a nie tylko eponimem tych miast. Po drugie, wybór padł na takie miejscowości, w których nazwach - niekiedy nieużywanych już potocznie - występuje człon iul-, dający się skojarzyć z imieniem Juliusz. Nazwy miast wzmiankowanych przez Kadłubka i przez jego następców, Lublina, Lubusza i Lubinia nie mają tego członu, ponieważ - jak wynika $z$ ich opowieści - zostały one wyparte przez bardziej swojskie, z członem lub-.

Motyw eponimiczny znika w ogóle w legendach o genezie dwóch niemieckich biskupstw, Merseburga i Magdeburga ${ }^{53}$. Zacznijmy od tego pierwszego miasta. Thietmar odnotował, że zostało ono założone i zagospodarowane przez Juliusza Cezara z rodu Romulusa, jakoby zięcia

Środkowo-Wschodnia. Ideologia, historia a społeczeństwo. Księga poświęcona pamięci Wojciecha Peltza, red. J. Dudek, D. Janiszewska, U. Świderska-Włodarczyk, Zielona Góra 2005, s. 335-350. Interesujący przykład może stanowić informacja Długosza o tym, że Litwini wspierali Pompejusza przeciwko Cezarowi (Ioannis Dlugossii Annales seu Cronicae incliti Regni Poloniae, t. 1, wyd. J. Dąbrowski, W. Semkowicz-Zarembina, K. Pieradzka, Varsaviae 1964, lib. I, s.a. 997, s. 215 n.; t. 6, wyd. K. Pieradzka, Z. Kozłowska-Budkowa, D. Turkowska, Varsaviae 1985, lib. X, s.a. 1385, s. 167 n.). O wspieraniu Pompejusza przez Gotów pisał z kolei Isidori Historia, cap. 3, s. 268 n.; o pokonaniu go przez Franków natomiast Fredegarii et aliorum Chronica, wyd. B. Krusch, MGH SrM, t. 2, Hannoverae 1888, lib. II, cap. 6, s. 46.

50 „pro qua nunc Forum Iulii, ita dictum, quod Iulius Caesar negotiationis forum ibi statuerat, habetur", Pauli Diaconi Historia Langobardorum, wyd. G. Waitz, MGH SrG in us. schol., Hannoverae 1878, lib. II, cap. 14, s. 96.

51 „Est autem locus ille proximus Iulo, a conditore Iulio Caesare cognominato”, Widukindi Monachi Corbeiensis Rerum Gestarum Saxonicarum libri tres, wyd. P. Hirsch, MGH SrG in us. schol., Hannoverae 1935, lib. II, cap. 1, s. 63.

52 O siostrze Cezara, vide A. Samsonowicz, Julia, w: SSS, t. 2, Wrocław [etc.] 1964, s. 343; J. Malinowska, Wizerunek kobiety w kronice Mistrza Wincentego, w: Studia z dziejów historii Polski i powszechnej od XIII do początków XIX wieku, red. J. Szymczak, Łódź 1999, s. 11.

53 Vide R. Michałowski, Zjazd Gnieźnieński. Religijne przesłanki powstania Arcybiskupstwa Gnieźnieńskiego, Wrocław 2005, s. 44 n. 
(czy szwagra - gener) Pompejusza ${ }^{54}$; nazwane zostało zaś nie od imienia swego założyciela, lecz od imienia Marsa, ponieważ jego mieszkańcy wykazywali się szczególną wojowniczością ${ }^{55}$. Cezar miał być także założycielem, ale nie eponimem, Magdeburga. Z Gesta archiepiscoporum dowiadujemy się, że Rzymianin ufundował nie tylko miasto, ale i świątynię Diany, w której umieścił liczne dziewice ${ }^{56}$. Ani w jednym, ani w drugim wypadku nie ma żadnego związku między imieniem założyciela a nazwą miasta. W obydwu jednak (a można tutaj uwzględnić także Lubiąż) związek z Cezarem podnosi znakomitość miejsca będącego siedzibą jakiejś instytucji kościelnej, diecezji albo klasztoru.

Wyróżniliśmy dwa obecne u Kadłubka wątki związane z Cezarem: zwycięstwo nad nim oraz miasto założone przez niego i nazwane od jego imienia. Pierwszy motyw znajduje analogie w gockiej tradycji historycznej, drugi m.in. w tradycji „ottońsko-pomorskiej”, a także u Pawła Diakona, Widukinda czy Thietmara. W żadnym z tych tekstów nie występują one obok siebie, tak jak u polskiego kronikarza, lecz rozłącznie. Zwłaszcza motyw miasta, pozbawiony kontekstu uprzedniego zwycięstwa nad Cezarem, zyskuje zupełnie inny sens. Nie chodzi tu tylko o szczególne znaczenie danej miejscowości. Zamiast niezależności od rzymskiego imperium,

${ }^{54}$ Również dwunastowieczny hagiograf króla Kanuta, Aelnoth z Canterbury, błędnie określił Cezara jako „zięcia (szwagra) Pompejusza” - Gesta Swenomagni regis et filiorum eius et Passio gloriosissimi Canuti regis et martyris, w: Vitae sanctorum Danorum, wyd. M.C. Gertz, København 1908-1912, prolog, s. 82. O tym źródle, vide A. Conti, Ælnoth of Canterbury and Early Mythopoiesis in Denmark, w: Saints and Their Lives on the Periphery. Veneration of Saints in Scandinavia and Eastern Europe (c. 1000-1200), red. H. Antonsson, I. Garipzanov, Turnhout 2010, s. 189-206.

${ }^{55}$ Kronika Thietmara, wyd. M.Z. Jedlicki, Poznań 1953, lib. I, cap. 2 (2), s. 5, 7. Niekiedy w dawniejszej literaturze przytaczano również inny passus Thietmara (lib. VI, cap. 59 (39), s. 399), zgodny jakoby z przekazem Kadłubka, a dotyczący jakoby Lubusza, vide A. Bielowski, w: Mierzwy kronika, s. 179, przyp. 5; O. Balzer, Studyum o Kadłubku, t. 1, Lwów 1934, s. 286 n.; H. Łowmiański, Początki Polski. Z dziejów Słowian w I tysiącleciu n.e., t. 5, Warszawa 1973, s. 330. Otóż biskup merseburski pisze najpierw o obsadzeniu w ciągu dwóch tygodni, jakie minęły od Ofiarowania Pańskiego, grodu w Lubuszu. Ciągnie dalej, że ,iuxta hanc [nieopodal Lubusza] in parte aquilonari stat civitas, quam a predicta [od Lubusza] nil nisi una vallis dividit". Tekst jest jednoznaczny, nie o Lubusz tu chodzi, tylko o pobliskie, wyraźnie od niego odróżnione miasto. I to ono właśnie (a nie Lubusz) wzbudzało w kronikarzu skojarzenia z budowlą wzniesioną przez Cezara: „Hanc cum diligenter lustrarem, opus Iulii Cesaris et magnam Romanorum structuram Lucano ammonente tractavi". Związek między owym pobliskim grodem a z jednej strony Lubuszem, z drugiej zaś Cezarem pozostaje jednak na tyle niejasny, że zestawianie tej wzmianki z opowieścią Kadłubka nie znajduje uzasadnienia.

${ }^{56}$ Gesta archiepiscoporum Magdeburgensium, wyd. W. Schum, MGH SS, t. 14, Hannoverae 1883 , cap. 2 , s. 377. 
oznacza raczej przynależność do niego - podobnie jak u cytowanego już wyżej poety Jansena Enikelsa ${ }^{57}$.

Kiedy mowa o Cezarze jedynie jako pokonanym najeźdźcy, jest on postacią jednoznacznie negatywną, a kiedy o fundatorze miasta - wówczas pozytywną. W obydwu połączonych rolach staje się on ambiwalentny. Z jednej strony jest potężnym wrogiem, ale pozostawia też coś po sobie $\mathrm{w}$ rodzimej kulturze ${ }^{58}$. W podobnej roli jak u Kadłubka występuje on we wczesnonowożytnej skandynawskiej opowieści o genezie święta Jul, w której również obydwa motywy zostały splecione ze sobą. Opowieść zapisana została w dwóch źródłach - w Kronice rymowanej Nielsa z Sorø, wydrukowanej po raz pierwszy w 1495 r. jako pierwszy duński inkunabut ${ }^{59}$, oraz w anonimowym islandzkim roczniku Oddveria Annáll ${ }^{60}$. Obydwie wersje różnią się jedynie drobnymi szczegółami, a ponieważ rocznik znany jest z jednego szesnastowiecznego odpisu (AM 417 4to), zakładano, że to wersja zapisana w kronice jest pierwotna ${ }^{61}$. Skoro jednak rocznik urywa się na roku 1427, to w znanej postaci może być on jak sądzę - odpisem wcześniejszej, piętnastowiecznej redakcji, i równie dobrze to kronikarz mógł czerpać z niego informacje, a nie na odwrót.

Opowieść ta przedstawia się następująco: Cezar, próbując podporządkować cały świat władzy Rzymian, zapragnął podbić również krainy leżące na północy. Niespodziewanie stawili mu jednak czoła Duńczycy, Szwedzi i Norwegowie pod wodzą dzielnego duńskiego króla Fridleifa Snare ${ }^{62}$. Gdy Cezar ujrzał ich potęgę, nie śmiał rozpocząć z nimi bitwy. W związku z tym, zawarł z nimi porozumienie, na mocy którego sprzymierzeni Skandynawowie mieli co roku radośnie świętować rocznicę jego

${ }^{57}$ J. Enikels, op. cit., v. 21083-21084, s. 414.

${ }^{58}$ Jedynie negatywną stronę wizerunku Cezara dostrzega ostatnio G. Vercamer, The Origins of the Polish Piast Dynasty as Chronicled by Bishop Vincent of Kraków (Wincenty Kadtubek) to Serve as a Political Model for His Own Contemporary Time, w: The Medieval Chronicle, red. E. Kooper, S. Levelt, t. 11, Leiden-Boston 2018, s. 228.

59 O tym źródle, vide P. Hermann, Politiske og astetiske aspekter i Rimkrøniken, „(Dansk) Historisk Tidsskrift” 107, 2007, 2, s. 389-411.

${ }^{60}$ O tym źródle, vide E. Pormóðsson, G.Á. Grímsdóttir, Formáli, w: Oddaannálar og Oddverjaannáll, wyd. E. pormóðsson, G.Á. Grímsdóttir, Reykjavík 2003, s. CIX-CLVI (cf. rec. tejże edycji, wraz ze zwięzłą charakterystyką rocznika, pióra H. Antonssona, „Saga-Book” 28, 2004, s. 108 n.).

61 Vide G. Storm, Forord, w: Islandske Annaler indtil 1578, Christiana 1888, s. XXXXV.

${ }^{62}$ Władca ten był już znany duńskiej historiografii średniowiecznej - Saxo Grammaticus, Gesta Danorum, lib. IV, cap. 10, s. 246-250. Sakso Gramatyk znał już obecny w późniejszych źródłach motyw należącej do Fridleifa kolczugi odpornej na żelazo, nie wiązał jednak tej postaci z Cezarem (ten z kolei pojawia się w innym miejscu jego kroniki, ale nie osobiście, a jedynie po to, by zasygnalizować, że duńskie dokonania z przeszłości przerastają te, które były udziałem Boskiego Juliusza - lib. VI, cap. 1, § 2, s. 356). 
urodzin, zwaną od jego imienia „Jul”. Tak było w czasach pogańskich, jednak wraz z chrystianizacją uroczystość ta wyparta została przez Boże Narodzenie. Wprawdzie o Cezarze słuch zaginął, a o genezie święta zapomniano, jednak nazwa została do tej pory zachowana ${ }^{63}$.

W opowieści tej zwraca przede wszystkim uwagę, że trzy narody skandynawskie występują ramię w ramię przeciwko Cezarowi pod wodzą władcy Danii. Zapewne stanowi to przeniesienie w odległa przeszłość realiów, gdy zawarta została unia kalmarska ${ }^{64}$. Byłby to $w$ takim razie przekaz, któremu ostateczny kształt nadano w wieku XV. Jeśli chodzi o konstrukcję narracyjną, historyjka ta jest łudząco podobna do opowieści o Lestku III. Zbieżności te robią tym większe wrażenie, że mamy do czynienia z przekazami niezależnymi od siebie, powstałymi w różnych kręgach kulturowych i w różnych okresach średniowiecza. W obydwu wypadkach Cezar ulega sile innego władcy i zawiera z tym władcą porozumienie (w wersji skandynawskiej - podobnie jak u Izydora z Sewilli w ogóle nie dochodzi do bitwy) ${ }^{65}$. W jednym wypadku porozumienie to wzbogacone zostaje dodatkowo o wątek perypetii matrymonialnych, którego brakuje w drugim. W obydwu zwycięstwo nad Cezarem pozostawia po sobie jakąś pamiątkę o nazwie urobionej od imienia Juliusz (dla analizy narracji nie ma znaczenia, że etymologia ta jest z językoznawczego punktu widzenia niepoprawna). Tą pamiątką są albo dwa miasta założone przez siostrę Cezara albo obchody jego urodzin. Można by na to rzec, że miasto i święto to dwie różne rzeczy; obydwa motywy pełnią jednak w strukturze opowieści taką samą funkcję (w Proppowskim sensie tego terminu $)^{66}$. Wreszcie, i tu, i tam owa „pamiątka po zwycięstwie” istnieje do tej pory, ale jej geneza z czasem zaciera się. W Polsce, w wyniku rywalizacji między dwiema kobietami dochodzi do zmiany nazw dwóch grodów, w Skandynawii natomiast nazwa święta wprawdzie zostaje zachowana, ale zmienia się jego charakter i nikt już nie pamięta, skąd się ono wzięło.

${ }^{63}$ Islandske Annaler, s. 430; Oddaannálar og Oddverjaannáll, s. 50 n.; Den Gammel-Danske Rimkrönike fra Sorø-Kloster, wyd. C.S. Ley, Kobenhavn 1841, s. 39 n.

${ }^{64}$ Vide J. Megaard, The Man who did not write Edda. Scemundr fróði and the Birth of Icelandic Literature, w: Scandinavia and Christian Europe in the Middle Ages. Papers of the $12^{\text {th }}$ International Saga Conference, red. R. Simek, J. Meurer, Bonn 2003, s. 380. Niezbyt przekonuje domysł Megaarda, jakoby etymologiczny chwyt w opowieści (nazwa Jul urobiona od imienia Juliusz) miał stanowić reminiscencję zaginionej twórczości Saemunda Mądrego. Megaard nie zwrócił również uwagi na przekaz Kroniki rymowanej.

${ }^{65}$ Zarówno Kadłubek, jak i dwaj skandynawscy autorzy twierdzą, że inicjatywa porozumienia wyszła od Cezara. W Kronice polskiej tymczasem to Lestek suwerennie podejmuje decyzję o zakończeniu wojny z Rzymianami i sprzymierzeniu się z nimi Chronicon Polonorum, s. 614.

${ }^{66}$ W. Propp, Morfologia bajki, Warszawa 1976 (oryg. ros. 1928). 
Zacieranie się cezariańskiej genezy różnych miast da się zaobserwować również na przykładach Lubiąża i Wolina. W pierwszym wypadku na miejscu pogańskiej świątyni stanął klasztor cysterski ufundowany przez Bolesława Wysokiego - a więc, tak jak ze świętem Jul, do zmiany dochodzi w wyniku chrystianizacji. W drugim z kolei, pierwotna nazwa Julin wraz $\mathrm{z}$ upływem czasu popada $\mathrm{w}$ niepamięć ${ }^{67}$. Podobne zjawisko miało stać się także udziałem walijskiej rzeki Habren, nazwanej tak przez królową Gwendolenę. Opowieść Geoffreya z Monmouth na jej temat zestawiano raczej z inną historią Kadłubka (a ściślej rzecz biorąc, Dzierzwy), mówiącą o Wandzie ${ }^{68}$. Może ona jednak i nam posłużyć jako materiał porównawczy. Jak podaje kronikarz, odsunięta przez męża Gwendolena pozbyła się rywalki, Estrildy, a także jej córeczki Habren, wrzucając obydwie do pewnej rzeki. Aby nie zapomniano nigdy o obydwu, władczyni nakazała zmienić nazwę owej rzeki na utworzoną od imienia dziewczynki „Habren”. Z biegiem czasu nazwa ta przekształciła się wszakże w „Sabrina” 69 . Motywem działania zarówno Gwendoleny, jak i nałożnicy Lestka III jest zazdrość o względy królewskiego małżonka. Ta pierwsza nadaje nazwę rzece, by nie zapomniano o jej rywalce, druga natomiast zmienia nazwy dwóch grodów po to właśnie, by o jej konkurentce zapomniano. W drugim wypadku operacja nazewnicza okazuje się trwała, a nowe nazwy grodów przyjmują się na stałe. W pierwszym tymczasem nazwa nadana odgórnie z czasem ustępuje miejsca innej, nowej.

Po przeprowadzeniu analizy porównawczej można pokusić się o hipotetyczną rekonstrukcję struktury narracyjnej opowieści o zwycięstwie nad Cezarem. Tworzyłoby ją kilka elementów, które w różnych, niezależnych przekazach występują w rozmaitych konfiguracjach. Także ją samą należałoby traktować jako byt idealny, który w narracjach kronikarskich zyskiwał jedynie cząstkowe realizacje, najpełniejsze bodaj w niektórych przeróbkach kroniki wincentyńskiej i w źródłach skandynawskich. Nie

${ }^{67}$ Pierwotny charakter nazwy „Julin” względem „Wolina” uznał za fakt historyczny M. Rudnicki, Studia nad nazwami rzek lechickich. Odra i jej ujścia, „Slavia Occidentalis” 15, 1936, s. 72 n.; cf. T. Lehr-Spławiński, O nazwie pomorskiego grodu Wolin-Julin u ujścia Odry, „Rocznik Gdański” 7-8, 1933, s. 41 n.

68 Vide M. Schlauch, Geoffrey of Monmouth and Early Polish Historiography. A Supplement, „Speculum” 44, 1969, 2, s. 258 n.; J. Banaszkiewicz, Polskie dzieje bajeczne, s. 113-118.

69 „Iubet [Guendoloena] enim Estrildidem et filiam eius Habren praecipitari in fluuium qui nunc Sabrina dicitur fecitque edictum per totam Britanniam ut flumen nomine puellae uocaretur; uolebat etenim honorem aeternitatis illi impendere quia maritus suus eam generauerat. Unde contigit quod usque in hunc diem appellatum est flumen Britannica lingua Habren, quod per corruptionem nominis alia lingua Sabrina uocatur", The Historia Regum Brittanie of Geoffrey of Monmouth, wyd. M.D. Reeve, Woodbridge 2007, lib. II, cap. 25, s. 35. 
należy jej również wiązać z żadnym konkretnym pierwowzorem literackim, ani tym bardziej z realnymi wydarzeniami z przeszłości. Schemat ten widzielibyśmy zatem następująco: Cezar jako pierwszy rzymski imperator (1) próbuje podporządkować sobie ludy spoza limesu (2); te stawiają mu opór, pokonując go w bitwie (3a) bądź zniechęcając do ataku (3b); zwycięski władca zawiera z Cezarem porozumienie (4), po którym pozostaje trwała pamiątka w postaci miasta lub święta, nazwanego od imienia Juliusz (5), jednak jej geneza z czasem zaciera się w pamięci zbiorowej (6). Niekiedy w opowieści pojawiały się również inne, współczesne Cezarowi postacie, np. pozostali dwaj triumwirowie czy jego rzekoma siostra, Julia. W sumie można powiedzieć, że średniowieczne narracje poświęcone rzymskiemu dyktatorowi były zbudowane z powtarzalnych elementów i nic w nich nie było pozostawione przypadkowi.

Na koniec zauważmy, że jeszcze w późnym średniowieczu opowieść Mistrza Wincentego była traktowana serio. Warto przyjrzeć się temu choćby pobieżnie. Z prawdziwą dumą przywoływał ją w swojej oracji Jan Ostroróg. Książęta śląscy, występując w 1459 r. przeciwko Jerzemu z Podiebradów, odwołali się do świadectwa annales nostri (czyli zapewne Kroniki ksiazzat polskich) i przedstawili jako potomkowie siostry Cezara, milczeniem pomijając przy tym związki z dynastią piastowską ${ }^{70}$. Dopiero Jan Bugenhagen przeprowadził quasi-naukową krytykę Kadłubkowego przekazu, zwracając uwagę na niezgodność z historią starożytną pewnych zawartych w nim szczegółów. Spostrzegł on, że Julia w rzeczywistości była córką, a nie siostrą Cezara, i wyszła za Pompejusza, Krassus zaś został pokonany przez Orodesa, a nie przez Lestka ${ }^{71}$. Miechowita zbył z kolei cezariańskie wątki milczeniem ${ }^{72}$, a Kromer określił je mianem fabuliosius $^{73}$. Równocześnie, zaobserwować można inną tendencję, polegającą na odnoszeniu wątków związanych z Cezarem do wczesnośredniowiecznych dziejów Słowian. Pierwszy krok poczynił tu bodaj Długosz,

70 Scriptores Rerum Silesiacarum, wyd. H. Markgraf, t. 8, Breslau 1873, no. 19, s. 17; cf. H. Manikowska, Świadomość regionalna na Śląsku w późnym średniowieczu, w: Państwo, naród, stany w świadomości wieków średnich. Pamięci Benedykta Zientary 1929-1983, red. A. Gieysztor, S. Gawlas, Warszawa 1990, s. 265 n.; P. Bering, Struktury narracyjne w póź nośredniowiecznych łacińskich kronikach regionalnych, Gniezno 2001, s. 43. Za potomka Cezara uważano również Karola IV - Kronika Jana z Marignoly, wyd. J. Emler, Praha 1882 (Fontes Rerum Bohemicarum, t. 3, V), prolog, s. 520; cf. M. Cetwiński, Juliusz Cezar w Lubiązu, s. 192 n.

${ }^{71}$ J. Bugenhagen, Pomerania, Gryphiswaldiae 1727, lib. I, cap. 4, s. 15 n. O tym źródle, vide M. Rusakiewicz, op. cit., s. 79-95.

72 Maciej z Miechowa, Chronica Polonorum, Kraków 1986, lib. I, s. XI.

${ }^{73}$ Martini Cromeri De origine et rebvs gestis Polonorum libri XXX, Basileæ 1568, lib. II, S. 24 . 
u którego Lestek nie miał nic wspólnego z Cezarem, nawet nie żył w jego czasach. Dziejopis utożsamił bowiem tego władcę ze znanym z roczników frankijskich czeskim księciem Lechem, poległym w bitwie z Karolem Wielkim ${ }^{74}$. Rzecz rozwinął polemicznie Marcin Bielski. Podobnie jak Ostroróg, utyskiwał on na tendencyjność „postronnych historyków, którzy nie pisali na on czas naszego szczęścia, iedno swoie, y to do więcey przyczyniali niż było, a naszy na ten czas pisać swoich dzieiow nie umieli, ani o to dbali. To iednak, pisali naszy, żeby z Juliuszem Cesarzem ten Leszko miał walczyć, y trzykroć z nim bitwę zwodzić, a Hetmana iego poimawszy, rosposzczone złoto mu lać w gębe, mowiąc: złota pragniecie Rzymianie, złoto piycie”. Zaraz potem Bielski zastrzegł: „ale się na czasiech barzo mylą: chybabychmy to o Karle Wielkim Cesarzu, ktory na ten czas panował, rozumieć chcieli". Polski władca miał nawet bawić kilkakrotnie w Akwizgranie ${ }^{75}$. Podobne poglądy pojawiały się w polskiej historiografii jeszcze przez kilkaset lat. Zdaniem Stanisława Zakrzewskiego bowiem, opowieść o Lestku III i Cezarze stanowić miała reminiscencję kontaktów polsko-karolińskich ${ }^{76}$, wedle Adama Naruszewicza zaś, Lestka III utożsamić można z Samonem ${ }^{77}$.

\section{Streszczenie}

Przedmiotem analizy jest opowieść Mistrza Wincentego o tym, jak po potrójnym zwycięstwie Lestka III nad Cezarem siostra pokonanego założyła w Polsce dwa grody, Lubusz i Lublin. Opowieść ta była zazwyczaj lekceważona przez dotychczasowych badaczy, aczkolwiek zwracano też uwagę, że miała ona podkreślać sięgającą dawnych czasów niezależność średniowiecznej Polski od Cesarstwa. Autor podejmuje próbę nowej interpretacji tej historyjki, wskazując na rozmaite analogie

${ }^{74}$ Ioannis Dlugossii Annales seu Cronicae, t. 1, lib. I, s. 106, 141 n. Vide D. Třeštik, Powstanie Wielkich Moraw. Morawianie, Czesi i Europa Środkowa w latach 791-871, Warszawa 2009 (oryg. czeski 2001), s. 116-118; Cz. Deptuła, Galla Anonima mit genezy, s. 323; P. Żmudzki, Kulturowy kontekst nazw, s. 200 n., przyp. 148.

${ }^{75}$ Kronika Polska Marcina Bielskiego, Warszawa 1829, s. 100 n. Znamienna jest tu degradacja Krassusa do roli „hetmana” Cezara.

76 Omówienie poglądów S. Zakrzewskiego, „Sprawozdania z czynności i posiedzeń Akademii Umiejętności w Krakowie" 15, 1910, 7, s. 26; cf. A. Brückner, Jana hr. Potockiego prace i zasługi naukowe, Warszawa 1911, s. 66 n.; A. Samsonowicz, op. cit., s. 343.

77 A. Naruszewicz, op. cit., t. 3, Lipsk 1836, s. 131; cf. J. Lelewel, Uwagi nad Mateuszem herbu Cholewa polskim XII wieku dziejopisem a w szczególności nad piérwsza dzieiów jego xięga, Warszawa-Wilno 1811, s. 122-125; H. Zeissberg, Vincentius Kadłubek, Bishof von Krakau (1208-1218; † 1223), und seine Chronik Polens. Zur Literaturgeschichte des dreizehnten Jahrhunderts, Wien 1869, s. 167. 
w dziejopisarstwie średniowiecznym (polskim, pomorskim, śląskim, niemieckim, gockim i skandynawskim). Wniosek, do jakiego prowadzi analiza porównawcza, jest taki, że zarówno motyw założenia miast przez Cezara, jak i poniesionej przez niego klęski militarnej, są obiegowymi motywami, które Kadłubek zespolił w jedną całość. Najbliżzzą analogię stanowi tu późnośredniowieczna skandynawska opowieść o genezie święta Jul.

\section{How to Tell the Story of the Victory over Caesar? An Attempt to Take a New Look at Master Vincentius' Account (I, 17)}

The subject of the analysis is Master Vincentius' story about how after the triple victory of Lestek III over Julius Caesar, the sister of the defeated founded two castles in Poland: Lebus and Lublin. This story was neglected by previous researchers, although it was also pointed out that one of its aims was to emphasize the independence of medieval Poland from the Empire, dating back to ancient times. The author attempts a new interpretation of this story, pointing to various analogies in medieval chronicles (Polish, Pomeranian, Silesian, German, Gothic and Scandinavian ones). The conclusion of this comparative analysis is that both the topic of a city founded by Caesar, and the military defeat he suffered are common motifs, combined by Kadłubek into one whole. The closest analogy is the late medieval Scandinavian tale of the origins of Yule season.

Translated by Grażyna Waluga

\section{Bibliografia}

Appian's Roman History, wyd. i tłum. Horace White, t. 2, Loeb Classical Library, London 1912

Augustyn ze Stargardu, Protokót, wyd. Edward Rymar, Muzeum, Stargard 2008.

Balzer Oswald, Studyum o Kadłubku, t. 1, nakł. TN, Lwów 1934.

Banaszkiewicz Jacek, Kronika Dzierzwy. XIV-wieczne kompendium historii ojczystej, Ossolineum, Wrocław 1979.

Banaszkiewicz Jacek, Mistrz Wincenty i naśladowcy - wizje najstarszych dziejów Polski XIII-XV wieku, w: Przeszłość w kulturze średniowiecznej Polski, red. Jacek Banaszkiewicz [et al.], t. 1, IH PAN, Neriton, Warszawa 2018, s. 269-306.

Banaszkiewicz Jacek, Polskie dzieje bajeczne Mistrza Wincentego Kadłubka, wyd. 2, Wydawnictwa Uniwersytetu Wrocławskiego, Wrocław 2002.

Beer Jeanette M.A., A Medieval Caesar, Droz, Genève 1976.

Bering Piotr, Struktury narracyjne w późnośredniowiecznych łacińskich kronikach regionalnych, Gnieźnieńska Oficyna Wydawnicza Tum, Gniezno 2001.

Bielowski August, Wstęp krytyczny do dziejów Polski, nakładem Włodzimierza Dzieduszyckiego, Lwów 1850. 
Bieniak Janusz, Mistrz Wincenty w życiu politycznym Polski przełomu XII i XIII wieku, w: Mistrz Wincenty Kadłubek. Człowiek i dzieło, pośmiertny kult i legenda, red. Krzysztof R. Prokop, PAU, Kraków 2001.

Brückner Aleksander, Jana hr. Potockiego prace i zasługi naukowe, Nakł. Gebethnera i Wolffa, Warszawa 1911.

Brückner Aleksander, Mitologia słowiańska i polska, wstęp i oprac. Stanisław Urbańczyk, PWN, Warszawa 1980.

Bugenhagen Johannes, Pomerania, Gryphiswaldiae 1727.

Cetwiński Marek, „Per totam civitatem ludos scenicos agi”. Teatr na Pomorzu w XII wieku?, w: idem, Metamorfozy ślaskie. Studia źródłoznawcze i historiograficzne, Wydawnictwo WSP, Częstochowa 2002, s. 15-19.

Cetwiński Marek, Imperium Lechitów. Polityczna doktryna czy opowieść ku pokrzepieniu serc?, w: idem, Metamorfozy ślaskie. Studia źródłoznawcze i historiograficzne, Wydawnictwo WSP, Częstochowa 2002, s. 71-77.

Cetwiński Marek, Juliusz Cezar w Lubiążu. Wokół pewnej wizji dziejopisarstwa ślaskiego, w: idem, Metamorfozy ślaskie. Studia źródłoznawcze i historiograficzne, Wydawnictwo WSP, Częstochowa 2002, s. 187-194.

Cetwiński Marek, Derwich Marek, Herby, legendy, dawne mity, KAW, Wrocław 1989. Cetwiński Marek, Podstępem czy siłą? „Działania specjalne” i ich moralna ocena $w$ kronikach ślaskich, „Średniowiecze polskie i powszechne” 2, 2002, s. 138-166.

Chmielewska Katarzyna, Rola wątków i motywów antycznych $w$ „Kronice polskiej” Mistrza Wincentego zwanego Kadłubkiem, Wydawnictwo WSP, Częstochowa 2003. Chronica Dzirsvae, wyd. Krzysztof Pawłowski, MPH n.s., t. 15, PAU, Kraków 2013. Chronica Poloniae Maioris, wyd. Brygida Kürbis, MPH n.s., t. 8, PWN, Warszawa 1970. Chronica Sigeberti Gemblacensis a. 381-1111, wyd. Ludwig C. Bethmann, MGH SS, t. 6, Impensis Bibliopolii Aulici Hahniani, Hannoverae 1844.

Chronicon Polonorum, wyd. Ludwik Ćwikliński, MPH, t. 3, Akademia Umiejętności w Krakowie, Lwów 1878.

Chronicon Polono-Silesiacarum, wyd. Wilhelm Arndt, MGH SS, t. 19, Impensis Bibliopolii Aulici Hahniani, Hannoverae 1866.

Chronicon principum Poloniae, wyd. Zygmunt Węclewski, MPH, t. 3, Akademia Umiejętności w Krakowie, Lwów 1878.

Cicero, Epistulae ad familiares, wyd. David Roy Shackleton Bailey, t. 2: 47-43 BC, Clarendon Press, Cambridge 2004.

Conti Aidan, Elnoth of Canterbury and Early Mythopoiesis in Denmark, w: Saints and Their Lives on the Periphery. Veneration of Saints in Scandinavia and Eastern Europe (c. 1000-1200), red. Haki Antonsson, Ildar Garipzanov, Brepols, Turnhout 2010, s. 189-206.

Dembińska Maria, Wędzki Andrzej, Lubiń, w: SSS, t. 3, Wrocław 1967, s. 96-98.

Den Gammel-Danske Rimkrönike fra Sorø-Kloster, wyd. Christian Sigfred. Ley, Fabritius de Tengnagel, Kobenhavn 1841.

Deptuła Czesław, Galla Anonima mit genezy Polski. Studium z historiozofii i hermeneutyki symboli dziejopisarstwa średniowiecznego, Instytut Europy Środkowo-Wschodniej, wyd. 2, Lublin 2000.

Deptuła Czesław, Ideologia Polski jako państwa morskiego w dziejopisarstwie polskim XIIXIV wieku, „Zeszyty Naukowe KUL” 18, 1975, 4, s. 3-17. 
Drelicharz Wojciech, Annalistyka małopolska XIII-XV wieku. Kierunki rozwoju wielkich roczników kompilowanych, PAU, Kraków 2003.

Drelicharz Wojciech, Idea zjednoczenia królestwa w średniowiecznym dziejopisarstwie polskim, Towarzystwo Naukowe Societas Vistulana, Kraków 2012.

Enikels Jansen, Weltchronik, wyd. Philipp Strauch, MGH Deutsche Chroniken, t. 3, Impensis Bibliopoli Hahniani, Hannoverae-Lipsiae 1900.

Eutropi Breviarium ab urbe condita, wyd. Hans Droysen, MGH Auctores antiquissimi, t. 2, apud Weidmannos, Berolini 1879.

Filipiuk Justyna, Kośnik Konrad, Słowiańskie teorie spiskowe jako pozanaukowe narracje historyczne, „Czas Kultury” 2, 2016, s. 83.

Fredegarii et aliorum Chronica, wyd. Bruno Krusch, MGH SrM, t. 2, Impensis Bibliopoli Hahniani, Hannoverae 1888.

Galli Anonymi Cronicae et gesta ducum sive principum Polonorum, wyd. Karol Maleczyński, MPH n.s., t. 2, PAU, Kraków 1952.

Gawlas Sławomir, Pytania o tożsamość średniowiecznych Polaków w świetle współczesnych dyskusji humanistyki, w: Symboliczne i realne podstawy tożsamości społecznej $w$ średniowieczu, red. Sławomir Gawlas, Paweł Żmudzki, Wydawnictwa Uniwersytetu Warszawskiego, Warszawa 2017, s. 15-82.

Gesta archiepiscoporum Magdeburgensium, wyd. Wilhelm Schum, MGH SS, t. 14, Impensis Bibliopoli Hahniani, Hannoverae 1883.

Gesta Swenomagni regis et filiorum eius et Passio gloriosissimi Canuti regis et martyris, w: Vitae sanctorum Danorum, wyd. Martin Clarentius Gertz, J. Jørgensen \& Co. (M.A. Hannover), København 1908-1912.

Gieysztor Aleksander, Leszek I, II, III, w: SSS, t. 3, Wrocław 1967, s. 48.

Gieysztor Aleksander, Mitologia Słowian, wyd. 3, Wydawnictwa Uniwersytetu Warszawskiego, Warszawa 2006.

Grabski Andrzej Feliks, Polska w opiniach obcych X-XIII w., PWN, Warszawa 1964. Gundolf Friedrich, Caesar in der deutschen Literatur, Mayer \& Müller, Berlin 1903. Gundolf Friedrich, Caesar. Geschichte seines Ruhms, Bondi, Berlin 1925.

Heck Roman, Chronica Principum Poloniae a Chronica Polonorum, Sobótka 31, 1976, 2, s. 185-196.

Heck Roman, Kronika książąt polskich - metoda prezentacji dziejów, w: Dawna historiografia ślaska. Materiały sesji odbytej w Brzegu w dniach 26-27 listopada 1977 roku, Wydawnictwo Instytutu Śląskiego, Opole 1977, s. 61-81.

Helmoldi Presbyteri Bozoviensis Cronica Slavorum, wyd. Bernhard Schmeidler, MGH SrG in us. schol., Impensis Bibliopoli Hahniani, Hannoverae 1937.

Hermann Pernille, Politiske og astetiske aspekter i Rimkrøniken, „(Dansk) Historisk Tidsskrift" 107, 2007, 2, s. 389-411.

Ioannis Dlugossii Annales seu Cronicae incliti Regni Poloniae, t. 1, wyd. Jan Dąbrowski, Wanda Semkowicz-Zarembina, Krystyna Pieradzka, PWN, Varsaviae 1964; t. 6, wyd. Krystyna Pieradzka, Zofia Kozłowska-Budkowa, Danuta Turkowska, PWN, Varsaviae 1973.

Iordanis, Getica, wyd. Theodor Mommsen, MGH Auctores antiquissimi, t. 5, 1, apud Weidmannos, Berolini 1882.

Isidori Hispalensis episcopi Etymologiarvm sive Originvm libri XX, wyd. Wallance Martin Lindsay, e Typographeo Clarendoniano, Oxonii 1911. 
Isidori Iunioris episcopi Hispalensis Historia Gothorum Wandalorum Sueborum, wyd. Theodor Mommsen, MGH Auctores antiquissimi, t. 11, apud Weidmannos, Berolini 1894.

Iustinus, Trogi Pompei Historiarum Philippicarum Epitoma, wyd. Justus Wilhelm Linde Jeep, in Aedibus B.G. Teubneri, Lipsiae 1859.

Jan z Dąbrówki, Commentum in Chronicam Polonorum Magistri Vincentii dicti Kadłubek, wyd. Marian Zwiercan [et al.], MPH n.s., t. 14, PAU, Kraków 2008.

Jurkiewicz Jan, Legenda o rzymskim pochodzeniu Litwinów w świetle historiografii. Czas powstania i tendencje polityczne, w: Europa Środkowo-Wschodnia. Ideologia, historia a społeczeństwo. Księga poświęcona pamięci Wojciecha Peltza, red. Jarosław Dudek Daria Janiszewska, Urszula Świderska-Włodarczyk, Oficyna Wydawnicza Uniwersytetu Zielonogórskiego, Zielona Góra 2005.

Kałuża Zenon, Lektury filozoficzne Wincentego Kadłubka. Zbiór studiów, Instytut Tomistyczny, Warszawa 2014.

Karp Marek J., Więź ogólnopolska i regionalna w średniowiecznych mitach początku, PH 72, 1981, 2, s. 211-227.

Kasperski Robert, Reges et gentes. Studia nad dyskursem legitymizujacym władze nad wspólnotami wyobrażonymi oraz strategiami ich konstruowania we wczesnym średniowieczu (VI-VII w.), IH PAN, Warszawa 2017.

Kiersnowski Ryszard, Legenda Winety. Studium historyczne, Wydawnictwo Studium Słowiańskiego UJ, Kraków 1950.

Kollinger Karol, Vincentiana. Materiały do bibliografii, w: Onus Athlanteum. Studia nad Kronika biskupa Wincentego, red. Andrzej Dąbrówka, Witold Wojtowicz, IBL PAN, Uniwersytet Szczeciński, Warszawa 2009, s. 476-527.

Komentarz Jana z Dąbrówki do Kroniki biskupa Wincentego, red. Andrzej Dąbrówka, Mikołaj Olszewski, IBL PAN, Stowarzyszenie Pro Cultura Litteraria, Warszawa 2015.

Konik Eugeniusz, Gajusz Juliusz Cezar w historiografii, „Annales UMCS”, sectio F Nauki Humanistyczne, 29, 1974, s. 33-41.

Kronika Jana z Marignoly, wyd. Josef Emler, nákladem Musea Království Českého, Praha 1882 (Fontes Rerum Bohemicarum, t. 3, V).

Kronika Polska Marcina Bielskiego, w Drukarni A. Gałęzowskiego i Komp., Warszawa 1829.

Kronika Thietmara, wyd. Marian Z. Jedlicki, Instytut Zachodni, Poznań 1953.

Kuczkowski Andrzej, Wolińska włócznia Juliusza Cezara - próba interpretacji, w: Kultura ludów Morza Bałtyckiego, t. 1: Starożytność i średniowiecze, red. Michał Bogacki, Maciej Franz, Zbigniew Pilarczyk, Wydawnictwo Adam Marszałek, Toruń 2008, s. $408-421$.

Kürbisówna Brygida, „Pollexianorum cervicosa feritas”. Dzikość i barbarzyństwo w opinii Mistrza Wincentego, w: Słowianie w dziejach Europy. Studia historyczne ku uczczeniu 75 rocznicy urodzin i 50-lecia pracy naukowej profesora Henryka Łowmiańskiego, red. Jerzy Ochmański, Wydawnictwo UAM, Poznań 1974.

Lanckorońska Karolina, Studies on the Roman-Slavonic Rite in Poland, Pontificium Institutum Orientalium Studiorum, Roma 1961.

Lehr-Spławiński Tadeusz, O nazwie pomorskiego grodu Wolin-Julin u ujścia Odry, „Rocznik Gdański” 7-8, 1933, s. 37-43. 
Lelewel Joachim, Uwagi nad Mateuszem herbu Cholewa polskim XII wieku dziejopisem, a w szczególności nad piérwsza dzieiów jego xięgą, nakł. i drukiem J. Zawadzkiego, Warszawa-Wilno 1811.

Lewandowski Ignacy, Mistrz Wincenty a Justyn - epitomator Pompejusza Troga, „Studia Źródłoznawcze" 20, 1976, s. 28-34.

Łowmiański Henryk, Początki Polski. Z dziejów Stowian w I tysiącleciu n.e., t. 5, PWN, Warszawa 1973.

Maciej z Miechowa, Chronica Polonorum, KAW, Kraków 1986.

Magistri Vincentii dicti Kadłubek Chronica Polonorum, wyd. Marian Plezia, MPH n.s., t. 11, PAU, Kraków 1994.

Makuch Piotr, Od Ariów do Sarmatów. Nieznane 2500 lat historii Polaków, Księgarnia Akademicka, Kraków 2013.

Małecki Antoni, Lechici w świetle historycznej krytyki, Komis H. Altenberga, wyd. 2, Lwów 1907.

Malinowska Jolanta, Wizerunek kobiety w kronice Mistrza Wincentego, w: Studia z dziejów historii Polski i powszechnej od XIII do początków XIX wieku, red. Jan Szymczak, Wydawnictwo Uniwersytetu Łódzkiego, Łódź 1999.

Manikowska Halina, Świadomość regionalna na Śląsku w późnym średniowieczu, w: Państwo, naród, stany w świadomości wieków średnich. Pamięci Benedykta Zientary 19291983, red. Aleksander Gieysztor, Sławomir Gawlas, PWN, Warszawa 1990.

Martini Cromeri De origine et rebvs gestis Polonorum libri XXX, per Ioannem Oporinum, Basileæ 1568.

Megaard John, The Man who did not write Edda. Scemundr fróði and the Birth of Icelandic Literature, w: Scandinavia and Christian Europe in the Middle Ages. Papers of the $12^{\text {th }}$ International Saga Conference, red. Rudolf Simek, Judith Meurer, Universität Bonn, Bonn 2003, s. 373-381.

Michałowski Roman, Princeps fundator. Studium $z$ dziejów kultury politycznej $w$ Polsce X-XIII wieku, wyd. 2, Arx Regia, Warszawa 1993.

Michałowski Roman, Zjazd Gnieźnieński. Religijne przesłanki powstania Arcybiskupstwa Gnieźnieńskiego, Wydawnictwo Uniwersytetu Wrocławskiego, Wrocław 2005.

Mierzwy kronika, wyd. August Bielowski, MPH, t. 2, nakład własny, Lwów 1872, s. $145-192$.

Mistrz Wincenty Kadłubek, Kronika Polska, przeł. Brygida Kürbis, Ossolineum, De Agostini, Wrocław 2003.

Moczulski Leszek, Narodziny Międzymorza. Uksztattowanie ojczyzn, powstanie państw oraz układy geopolityczne wschodniej części Europy w późnej starożytności i we wczesnym średniowieczu, Bellona, Warszawa 2007.

Mowa Ostroroga wobec papieża Pawła II (1467), w: Humanizm i reformacja w Polsce. Wybór źródeł dla ćwiczeń uniwersyteckich, wyd. Ignacy Chrzanowski, Stanisław Kot, Ossolineum, Lwów 1927, s. 56-60.

Mrozowicz Wojciech, Śląska Kronika Polska. Wstęp do studium źródłoznawczego, cz. 1, w: Studia z historii średniowiecza, red. Mateusz Goliński, Wydawnictwo Uniwersytetu Wrocławskiego, Wrocław 2003.

Mrozowicz Wojciech, Z problematyki recepcji Kroniki Wincentego w średniowiecznym dziejopisarstwie polskim (ze szczególnym uwzględnieniem ślaskiej Kroniki Polskiej), 
w: Onus Athlanteum. Studia nad Kronika biskupa Wincentego, red. Andrzej Dąbrówka, Witold Wojtowicz, IBL PAN, Uniwersytet Szczeciński, Warszawa 2009, s. $326-336$.

Mularczyk Jerzy, Kronika Polska i jej relacja o bitwie pod Studnica, KH 95, 1988, 2, s. $25-56$.

Myśliwski Grzegorz, Archetypy i historia. Uwagi o „Polskich dziejach bajecznych mistrza Wincentego Kadłubka" Jacka Banaszkiewicza, PH 90, 1999, 4, s. 541-551.

Naruszewicz Adam, Historya Narodu Polskiego, t. 3-4, Breitkopf \& Haertel, Lipsk 1836. Nearing Homer jr., Local Caesar Traditions in Britain, „Speculum” 24, 1949, 2, s. 218-227. Notula satis notabilis de Pomeranorum, Stetinensium, ac Rugie principatu, wyd. Johann Gottfried Ludwig Kosegarten, „Baltische Studien” 17, 1858, 1, s. 103-140.

Obremski Krzysztof, Panegiryczna sztuka postaciowania. August II Mocny, Wydawnictwo UMK, Toruń 2003.

Oddaannálar og Oddverjaannáll, wyd. Eiríkur Pormóðsson, Guðrún Ása Grímsdóttir, Reykjavík 2003.

Orose, Histoires (contre les païens), wyd. Marie-Pierre Arnaud-Lindet, Persée, Paris 2003.

Pandowska Danuta, Włócznia Juliusza Cezara w Wolinie, „Słupskie Studia Historyczne” 5, 1997, s. 27-37.

Pauli Diaconi Historia Langobardorum, wyd. Georg Waitz, MGH SrG in us. schol., Impensis Bibliopoli Hahniani, Hannoverae 1878.

Pleszczyński Andrzej, Sobiesiak Joanna, Szejgiec Karol, Tomaszek Michał, Tyszka Przemysław, Historia communitatem facit. Struktura narracji tworzacych tożsamości grupowe w średniowieczu, Chronicon, Wrocław 2016.

Pleszczyński Andrzej, Przekazy niemieckie o Polsce i jej mieszkańcach w okresie panowania Piastów, Wydawnictwo UMCS, Lublin 2016.

Plezia Marian, Dialog w kronice Kadłubka, w: idem, Scripta minora. Łacina średniowieczna i Wincenty Kadłubek, DWN, Kraków 2001, s. 217-227.

Propp Włodzimierz, Morfologia bajki, Książka i Wiedza, Warszawa 1976.

Q. Curtii Rufi De Gestis Alexandri Magni regis Macedonum libri qui supersunt octo, wyd. Julius Mützell, t. 1, apud Fr. Vieweg et filium, Berlin 1841.

Reydellet Marc, La royauté dans la littérature latine de Sidoine Apollinaire à Isidore de Séville, Persée, Rome 1981.

Rocznik Kapituły Krakowskiej, wyd. Zofia Kozłowska-Budkowa, MPH n.s., t. 5, PWN, Warszawa 1978.

Rosik Stanisław, Conversio gentis Pomeranorum. Studium świadectwa o wydarzeniu (XII wiek), Chronicon, Wrocław 2010.

Rudnicki Mikołaj, Studia nad nazwami rzek lechickich. Odra ijej ujścia, „Slavia Occidentalis" 15, 1936, s. 46-101.

Rusakiewicz Monika, Wineta. Korzenie legendy i jej recepcja $w$ historiografii zachodniopomorskiej do XVI wieku, Chronicon, Wrocław 2016.

Samsonowicz Agnieszka, Julia, w: SSS, t. 2, Wrocław [etc.] 1964.

Saxo Grammaticus, Gesta Danorum. The History of the Danes, wyd. Karsten Friis-Jensen, t. 1-2, Clarendon Press, Oxford 2015.

Schlauch Margaret, Geoffrey of Monmouth and Early Polish Historiography. A Supplement, „Speculum” 44, 1969, 2, s. 258-263. 
Scriptores Rerum Silesiacarum, wyd. Hermann Markgraf, t. 8, Josef Max \& Comp., Breslau 1873.

Sikorski Dariusz Andrzej, Religie dawnych Słowian. Przewodnik dla zdezorientowanych, Wydawnictwo Poznańskie, Poznań 2018.

Skibiński Edward, Początki Polski w Kronice Polskiej i w Kronice Dzierzwy, w: Cognitioni Gestorum. Studia z dziejów średniowiecza dedykowane Profesorowi Jerzemu Strzelczykowi, red. Dariusz A. Sikorski, Andrzej M. Wyrwa, DiG, Poznań-Warszawa 2006, s. 196-203.

Ślaski Kazimierz, Wątki historyczne w podaniach o początkach Polski, PWN, Poznań 1968.

Słupecki Leszek P., Slavonic pagan sanctuaries, Institute of Archeology and Ethnology. Polish Academy of Sciences, Warsaw 1994.

Storm Gustav, Forord, w: Islandske Annaler indtil 1578, Grøndahl \& Søns Bogtrykkeri, Christiana 1888.

Strzelczyk Jerzy, Juliusz Cezar w tradycji wieków średnich, w: idem, $W$ świecie średniowiecznych myśli i emocji. Wybór prac, Instytut Historii UAM, Poznań 2012, s. $159-170$.

Tazbir Janusz, Od antemurale do przedmurza, dzieje terminu, OiRP 29, 1984, s. 166-184. The Historia Regum Brittanie of Geoffrey of Monmouth, wyd. Michael D. Reeve, The Boydell Press, Woodbridge 2007.

Thomas Heinz, Julius Caesar und die Deutschen. Zu Ursprung und Gestalt eines deutschen Geschichtsbewusstseins in der Zeit Gregors VII. und Heinrichs IV., w: Die Salier und das Reich, t. 3: Gesellschaftlicher und ideengeschichtlicher Wandel im Reich der Salier, red. Stefan Weinfurter [et al.], Thorbecke, Sigmaringen 1991.

Třeštik Dušan, Powstanie Wielkich Moraw. Morawianie, Czesi i Europa Środkowa w latach 791-871, Wydawnictwa UW, Warszawa 2009.

Tymieniecki Kazimierz, Polska legenda średniowieczna, „Przeszłość” 7, 1935, 4, s. 55-57.

Vercamer Grischa, The Origins of the Polish Piast Dynasty as Chronicled by Bishop Vincent of Kraków (Wincenty Kadlubek) to Serve as a Political Model for His Own Contemporary Time, w: The Medieval Chronicle, red. Erik Kooper, Sjoerd Levelt, t. 11, Leiden-Boston 2018.

Versus Lubenses, wyd. August Bielowski, MPH, t. 3, W Komisie Księgarni Gubrynowicza i Schmidta, Lwów 1878.

Walczak Ryszard, „Protocollum” augustianina-eremity zwanego Angelusem ze Stargardu. O polsko-pomorskich zwiazkach historiograficznych w średniowieczu, PTPN, Poznań 1991.

Węcowski Piotr, Początki Polski w pamięci historycznej późnego średniowiecza, Societas Vistulana, Kraków 2014.

Widukindi Monachi Corbeiensis Rerum Gestarum Saxonicarum libri tres, wyd. Paul Hirsch, MGH SrG in us. schol., Impensis Bibliopolii Hahniani, Hannoverae 1935.

Wiersze wywołane mowa Ostroroga, w: Humanizm i reformacja w Polsce. Wybór źródeł dla ćwiczeń uniwersyteckich, wyd. Ignacy Chrzanowski, Stanisław Kot, Ossolineum, Lwów 1927, s. 58-60.

Wood Jamie, The Politics of Identity in Visigothic Spain. Religion and Power in the Histories of Isidore of Seville, Brill, Leiden-Boston 2012. 
Zeissberg Heinrich, Vincentius Kadłubek, Bishof von Krakau (1208-1218; † 1223), und seine Chronik Polens. Zur Literaturgeschichte des dreizehnten Jahrhunderts, aus der K.K. Hof- und Staatsdruckerei, in Commission bei Karl Gerold's Sohn, Buchhändler der kaiserlichen Akademie der Wissenschaften, Wien 1869.

Żmudzki Paweł, Kulturowy kontekst nazw „Polanie”, „Polacy”, „Polska” w średniowiecznej historiografii polskiej i ruskiej, w: Symboliczne i realne podstawy tożsamości społecznej w średniowieczu, red. Sławomir Gawlas, Paweł Żmudzki, Wydawnictwa Uniwersytetu Warszawskiego, Warszawa 2017, s. 165-219.

Żmudzki Paweł, Vincentius's Construct of a Nation. Poland as Res Publica, w: Writing History in Medieval Poland. Bishop Vincentius of Cracow and the Chronica Polonorum, red. Darius von Güttner-Sporzyński, Brepols Publishers, Turnhout 2017, s. 175-197.

Żmudzki Paweł, Władca i wojownicy. Narracje o wodzach, drużynie i wojnach w najdawniejszej historiografii Polski i Rusi, Wydawnictwo Uniwersytetu Wrocławskiego, Wrocław 2009.

Żuchowicz Roman, Wielka Lechia. Źródła i przyczyny popularności teorii pseudonaukowej okiem historyka, Sub Lupa, Warszawa 2018.

Zwiercan Marian, Komentarz Jana z Dąbrówki do Kroniki Mistrza Wincentego zwanego Kadłubkiem, Ossolineum, Wrocław 1969.

Biog ram: dr Rafał Rutkowski, współpracownik Instytutu Historii PAN w Warszawie. Zainteresowania badawcze: historia historiografii średniowiecznej, historia średniowiecznej Skandynawii; kontakt: rr.rutkowski@wp.pl. 